\title{
One Dimensional Evolution Modeling of Source Rocks in the Chaluhe Basin, Yitong Graben
}

\author{
Obed Kweku Agbadze*, Jiaren Ye, Qiang Cao \\ Key Laboratory of Tectonics and Petroleum Resources, China University of Geosciences, MOE, Wuhan, China \\ Email: "t2text@yahoo.com
}

Received 5 June 2016; accepted 16 August 2016; published 19 August 2016

Copyright @ 2016 by authors and Scientific Research Publishing Inc.

This work is licensed under the Creative Commons Attribution International License (CC BY).

http://creativecommons.org/licenses/by/4.0/

(c) (7) Open Access

\begin{abstract}
Chaluhe Basin is in Jilin Province of China with a cumulative sedimentary rock thickness of about 6000 meters and has four subdivisions: Wanchang Structural High, Bo-Tai Sag, Xinanpu Sag, Liangjia Structure High and the Gudian Slope. The basin with its better source rock distribution and more favorable maturation indicators than the adjacent Moliqing and Luxiang Basins is expected to be a potential hydrocarbon-producing basin. Four (4) wells were used in determining the maturation hydrocarbon generating potential of the mudstone beds present in the Eocene Formations (Shuangyang, Sheling and Yongji). Obtained result revealed heat flow average of 71.8 $\mathrm{mW} / \mathrm{m}^{2}$, oil generation between $3.15 \mathrm{mg} / \mathrm{g}$ TOC and $39.49 \mathrm{mg} / \mathrm{g}$ TOC with gas generation of 6.98 $\mathrm{mg} / \mathrm{g}$ TOC to $92.83 \mathrm{mg} / \mathrm{g}$ TOC. In conclusion the Eocene Shuangyang mudstone is the main petroleum source rock.
\end{abstract}

\section{Keywords}

Petrophysics, Petrochemicals, Hydrocarbons, Eocene Mudstone, Chaluhe Basin, Yitong Graben

\section{Introduction}

The Chaluhe Basin is one of the three basins in the Yitong Graben, namely Moliqing and Luxiang basins. It lies in the north of the Yitong Graben, and is located between the Changchun city and Jilin city of Jilin province and covers an area of approximately $1350 \mathrm{~km}^{2}$, with cenozoic sediments up to $6000 \mathrm{~m}$ (Figure 1). The Chaluhe Basin can be divided into the Liangjia Structural High, the Xinanpu Sag, the Wanchang Structural High, the Bo-Tai Sag and the Gudian Slope (Figure 2).

"Corresponding author.

How to cite this paper: Agbadze, O.K., Ye, J.R. and Cao, Q. (2016) One Dimensional Evolution Modeling of Source Rocks in the Chaluhe Basin, Yitong Graben. International Journal of Geosciences, 7, 1029-1048.

http://dx.doi.org/10.4236/ijg.2016.78078 


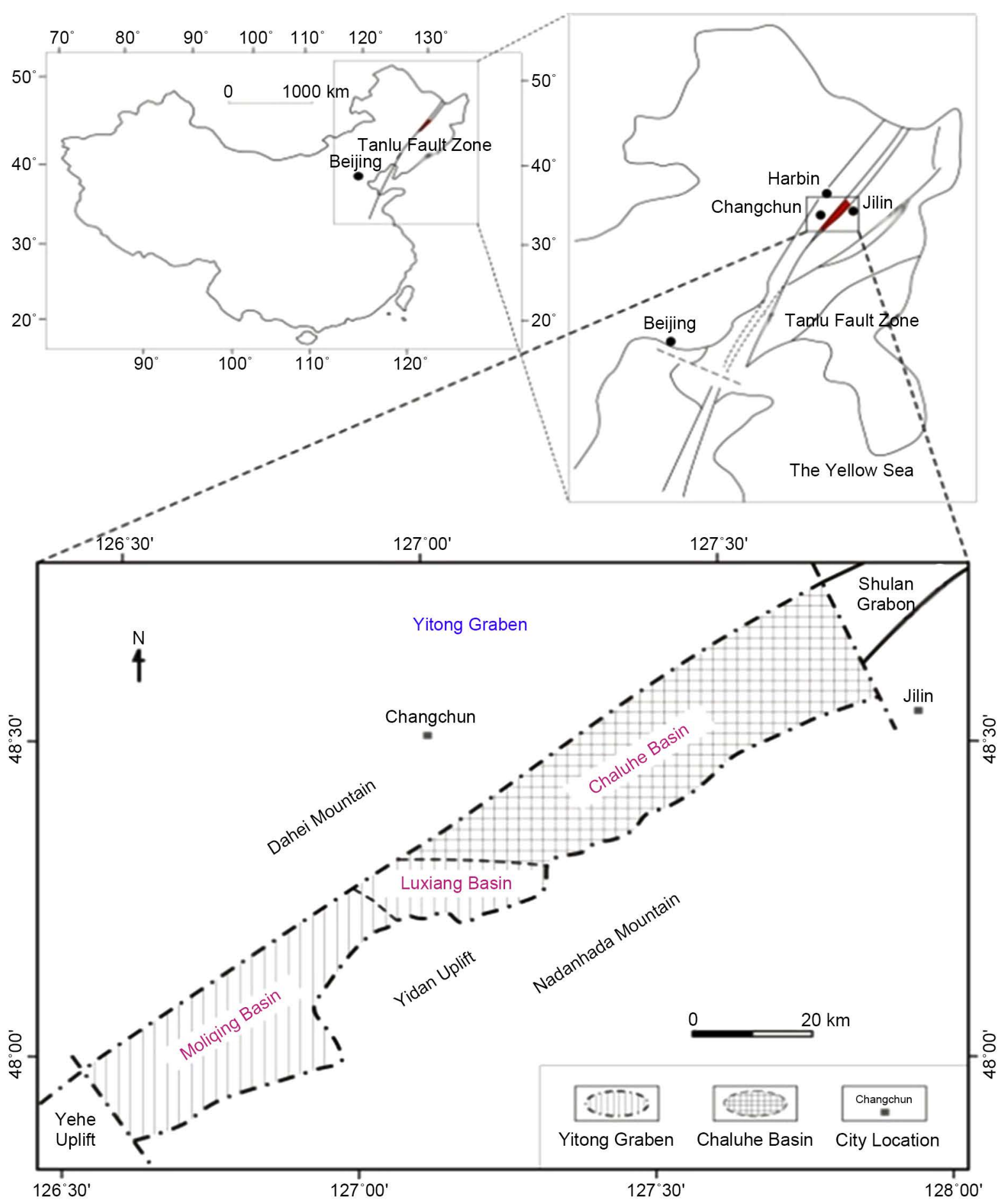

Figure 1. A map showing the location of the Chaluhe Basin.

Based on apatite fission track analysis of some few samples from Chaluhe Basin and basin modeling study, it can be concluded that since the Oligocene (36.6 Ma) in the Graben, the Chaluhe Basin has undergone two episodes of uplift during 24.9 - 19.1 Ma and 6.9 - 4.9 Ma, with an average apparent exhumation rate to be 70.34 and since 21.8 Ma. The results of thermochronological analysis can also be supported by the evidence from geological relationships such as geodynamics, volcanic activity, and stratigraphic division and correlation [1].

So far, more than 50 wells have been drilled in the basin. To date the overall exploration within the Chaluhe 


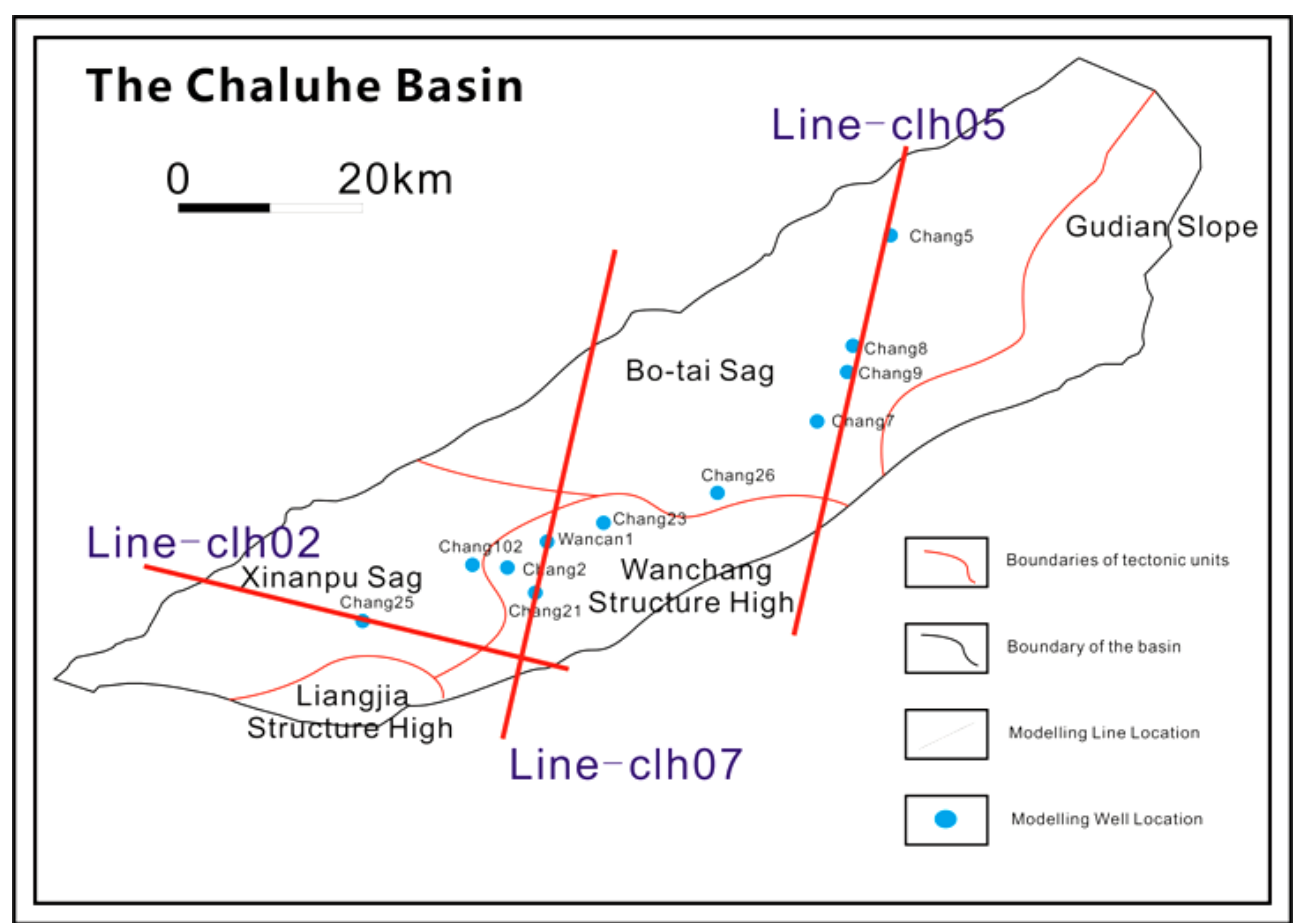

Figure 2. A map showing the Wells, Seismic lines for this study and the subdivisions of the Chaluhe Basin, the Yitong Graben.

Basin has not been very successful and only local hydrocarbon production has been discovered. In contrast, the Moliqing and Changchun oilfields have been found in the Moliqing and Luxiang basins in the SW part of Yitong Graben, with reserves of $3317 \times 10^{4}$ t oil and $13.29 \times 10^{8} \mathrm{~m}^{3}$ gas. The Chaluhe Basin has similar Cenozoic sediments and tectonic setting to the adjacent Moliqing and Luxiang basins, and widespread distribution better source rocks and more favorable condition of hydrocarbon accumulation which suggests that the Chaluhe Basin should have a great potential of hydrocarbons and can be considered as the prime targets for future hydrocarbon exploration within the Yitong Graben.

\section{Geological Settings}

The Yitong Graben is a petroliferous late-Mesozoic and Cenozoic slip-extensional basin located at the north east of China between the cities of Changchun and Jilin. This basin makes part of the Tanlu fault zone which is one of the largest continental strike-slip faults in the world [2].

The formation and development of the Yitong Graben mainly resulted from the collision between the Indian plate and the Eurasian plate, and the subduction of the Pacific plate to the Eurasian plate [3] trending NNW during the Early Eocene. During this period, three reverses and uplifts occurred in the Middle Eocene, Late Oligocene and Late Miocene [4].

The Yitong Graben consist of three basins namely, Chaluhe, Moliqing and Luxiang basins, and is an oilbearing geological structure with unique characteristics in Northeast China. On the basis of apatite fission track ages and geological relationship, the tectonic uplift history of the Yitong Graben since the Oligocene was discussed. The results of thermochronological analysis can also be supported by the evidence from geological relationships such as geodynamics, volcanic activity, and stratigraphic division and correlation.

Evidence from geodynamics background suggests that the tectonic stress field of the Yitong Graben changed from tenso-shear to compresso-shear during the Cenozoic [5], which is related mainly to the alteration of subduction direction from the Pacific plate to the Eurasian plate. The subduction was diagonally conducted from the Pacific plate to the Eurasian plate in direction from SSE to NNW during the Early Eocene, which resulted in the formation of the Yitong Graben. However, the subduction direction of the Pacific plate to the Eurasian plate has changed into EW direction since the Oligocene, which resulted in a series of phenomena related to compression stress field such as the thrust-motion of Tanlu fault zone [6] [7], regional uplift, and intense folding and defor- 
mation within the Wanchang-Qijia formations in northwestern Yitong Graben.

\section{Materials and Methods}

\subsection{Materials and Input Parameters}

The materials and input data required to run the BasinMod 1-D of this study includes the present thicknesses of each stratigraphic unit, top and base wellbore depths, and the lithology mixes. Biostratigraphy is derived from the washing of ditch cuttings, sidewall cores and conventional cores which are then separated and analyzed for micro fauna (Foraminifera) and flora (spores and pollens) so as to ascribe a presumed age to each interval studied. Kerogen types, total organic carbon (TOC), kinetic algorithms and results of pyrolysis analyses, the location of wells, and organic thermal indicators include vitrinite reflectance values; the water-sediment interface temperatures [8] and subsurface bottom hole temperatures (BHTs) through time, the short term sea level proposed by [9] [10], geologic time scale 1989 Harland, the density of asthenosphere $(\rho \mathrm{m})$ and water $(\rho \mathrm{w})$ are 3.40 $\mathrm{g} / \mathrm{cm}^{3}$ and $1.03 \mathrm{~g} / \mathrm{cm}^{3}$ respectively, the Beta factor $(\beta)$ and thickness of lithosphere (a) are obtained accepting default values of 2 and $125 \mathrm{~km}$, respectively, all mixed parameters, the initial porosity, reciprocal and exponential compaction factors, the matrix density, matrix thermal conductivity, and matrix heat capacity are adopted from the default values in BasinMod Software package.

\subsection{Formations}

Drilling, logging and paleontological studies reveal the Chaluhe basin contains seven different sedimentary rocks formations from the Eocene to the Quaternary with scattered Neogene formation in the Cretaceous and Jurassic outcrops, overlying a pre-tertiary basement (Figure 3). The distribution of the sediment thicknesses inside the Chaluhe depression is deeper at the northern area of the basin, diminishing in depth towards the southern zone. Furthermore, the total thickness of the sediments ranges from $2000 \mathrm{~m}$ to $6000 \mathrm{~m}$.

\subsection{Maturity Calculation}

For maturity calculation, a number of methods are available but the Lopatin TTI method is employed in this research.

The Time Temperature Index (TTI) method for calculating maturity is the Lopatin (1971) application of the assumption that the maturity reaction doubles for every 10 degree Celsius increase in temperature. This simple method has been widely used for basin modeling since it was popularized by Waples (1980). The TTI method provides reasonable prediction capabilities and direct empirical correlation to vitrinite reflectance (Ro), as well as to other measured maturity indicators such as TAI and TMAX. BasinMod provides several methods for conversion of TTI to \%Ro. The user may select from the conversion constants of Goff, Hood et al., Issler, Royden, Waples, or Dykstra. The user may enter his/her conversion constants with the "User" option. Another alternative is to define the conversion of \%Ro to TTI using the "Table" option. BasinMod accepts conversions for TAI and TMAX as well as a third maturity indicator which can be labeled by the user. Spore Color Index (SCI) or Conodont Alteration Index (CAI) is two of the other indices that can be used for TTI to \%Ro conversion. Major companies usually have standard correlations for these indices.

\subsection{Present Day Temperature Field}

Comprehensive analysis of the test drilling data shows presently high geothermal gradient in the Chaluhe Basin with $3.36^{\circ} \mathrm{C} / 100 \mathrm{~m}$ (Figure 4); longitudinally, geothermal gradient increasing with depth.

Further analysis of the basin reveals geothermal gradient differences in tectonic units (Table 1). Chaluhe Bo-Tai Sag well Chang 7 has the lowest geothermal gradient of $3.38^{\circ} \mathrm{C} / 100 \mathrm{~m}$, followed by well WC 1 in the Wanchang Structural belt with $\left(3.44^{\circ} \mathrm{C} / 100 \mathrm{~m}\right)$, and then the Xinanpu Sag well Chang 25 with geothermal gradient of $3.54^{\circ} \mathrm{C} / 100 \mathrm{~m}$.

\section{Result Interpretation and Discussion}

It is of essence to re-emphasize that, this study, as its topic clearly states deals only with one dimensional model of the source rocks (units) of the study area, being the Chaluhe Basin of the Yitong Graben. 
O. K. Agbadze et al.
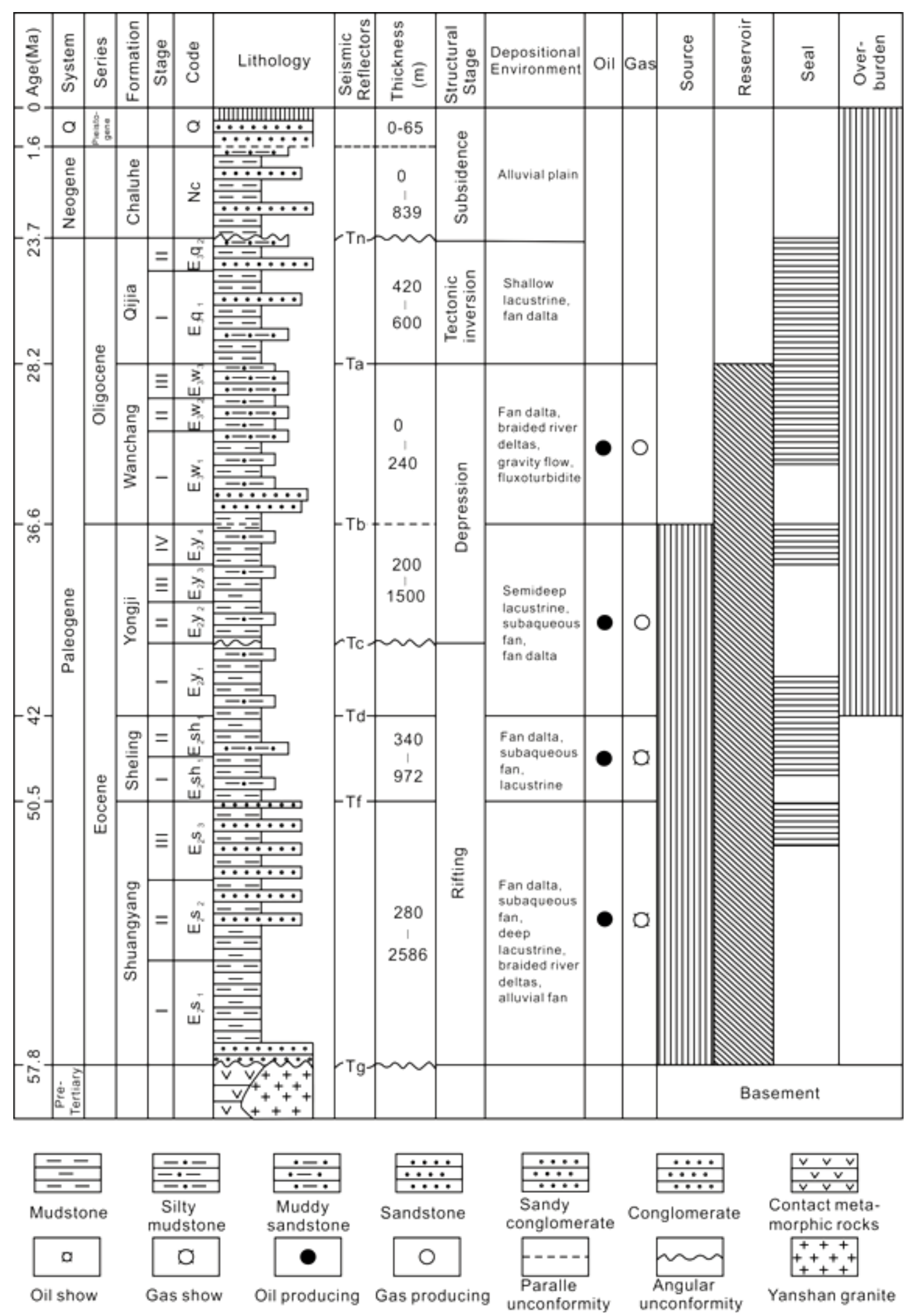

Figure 3. Stratigraphic columns in the Chaluhe basin detailing the lithology and rock types. 


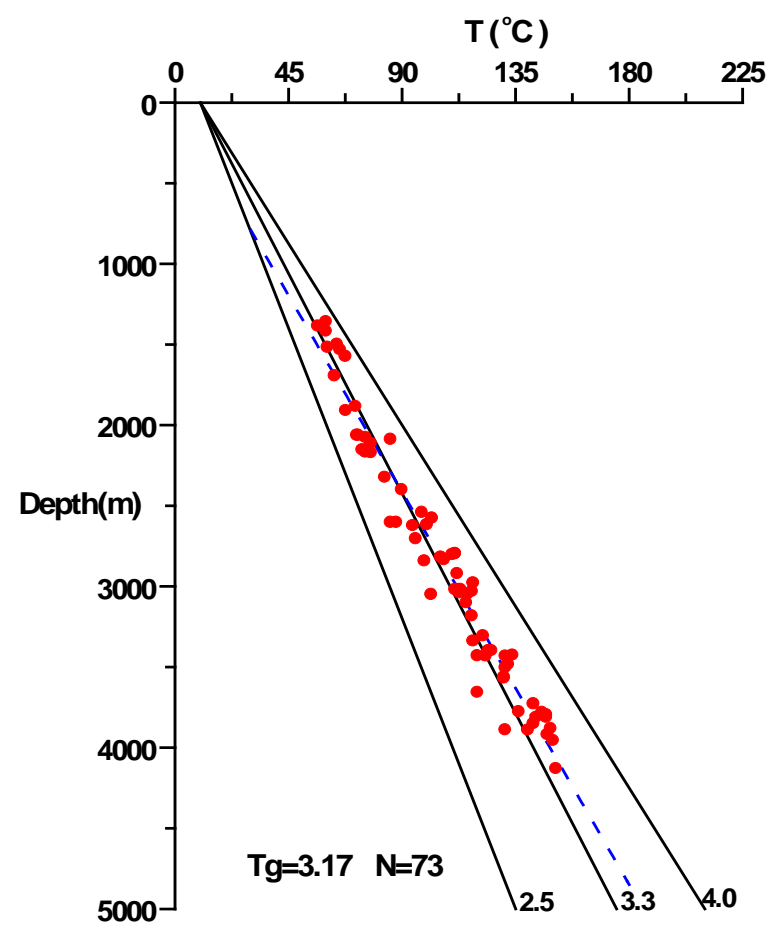

Figure 4. Chaluhe Basin geothermal gradients.

Table 1. Chaluhe Basin present day geothermal gradient.

\begin{tabular}{cccc}
\hline & Tectonic units & Well name & Present geothermal gradient $\left({ }^{\circ} \mathrm{C} / 100 \mathrm{~m}\right)$ \\
\hline \multirow{3}{*}{$\begin{array}{c}\text { Chaluhe } \\
\text { Basin }\end{array}$} & Bo-Tai Sag & Chang 7 & 3.22 \\
& Wanchang Structural Belt & WC 1 & 3.44 \\
& Xinanpu Sag & Chang 25 & 3.54 \\
\hline
\end{tabular}

\subsection{Burial History and Tectonic Subsidence History}

On the basis of geological studies, drilling, geophysical and analytical testing and other information on the history were combined with logging data to determine facies and eroded thickness, and seismic profiles, for calibration to model the burial history and sedimentary deposition in the basin (Figure 5(a) to Figure 5(h)).

1) Based on the burial and subsidence models of Wells Chang 7 and 8 (Figure 5(a), Figure 5(b), Figure 5(c) and Figure 5(d)) in Bo-Tai sag of the basin, three-stages could be identified, that is, from Neogeneto Quaternary, Neogene and Paleogene. Between Yongji formation and Sheling Formation, three uplifts of sedimentary boundaries and an erosion cycle occurred. The first erosion event was short, followed by a second which was long and the third longer. The maximum depth and sedimentary deposition of $4400 \mathrm{~m}$ and $4600 \mathrm{~m}$ was attained respectively.

Deposition rate and the rate of evolution of tectonic subsidence are consistency when the deposition rate is positive, the sedimentation rate is also positive, the deposition rate is negative, the sedimentation rate is also negative and also consistent with each other, but in this model, the size of the deposition rate and subsidence rate are inconsistent.

2) According to the burial and subsidence model of Well Chang 25 (Figure 5(e), Figure 5(f)) in the Xinanpu sag, the well's burial curve revealed a two-stage event, the first erosion took place during the Neogene, that's during the fourth deposition and for a short duration, then between the second group of deposition; Yongji formation and Sheling group, and for a longer duration. The maximum depth of deposition is $4700 \mathrm{~m}$. Deposition rate and the rate of evolution of tectonic subsidence are consistent, with consistent positive and negative characteristics, but its size of deposition rate and subsidence rate are inconsistent. 


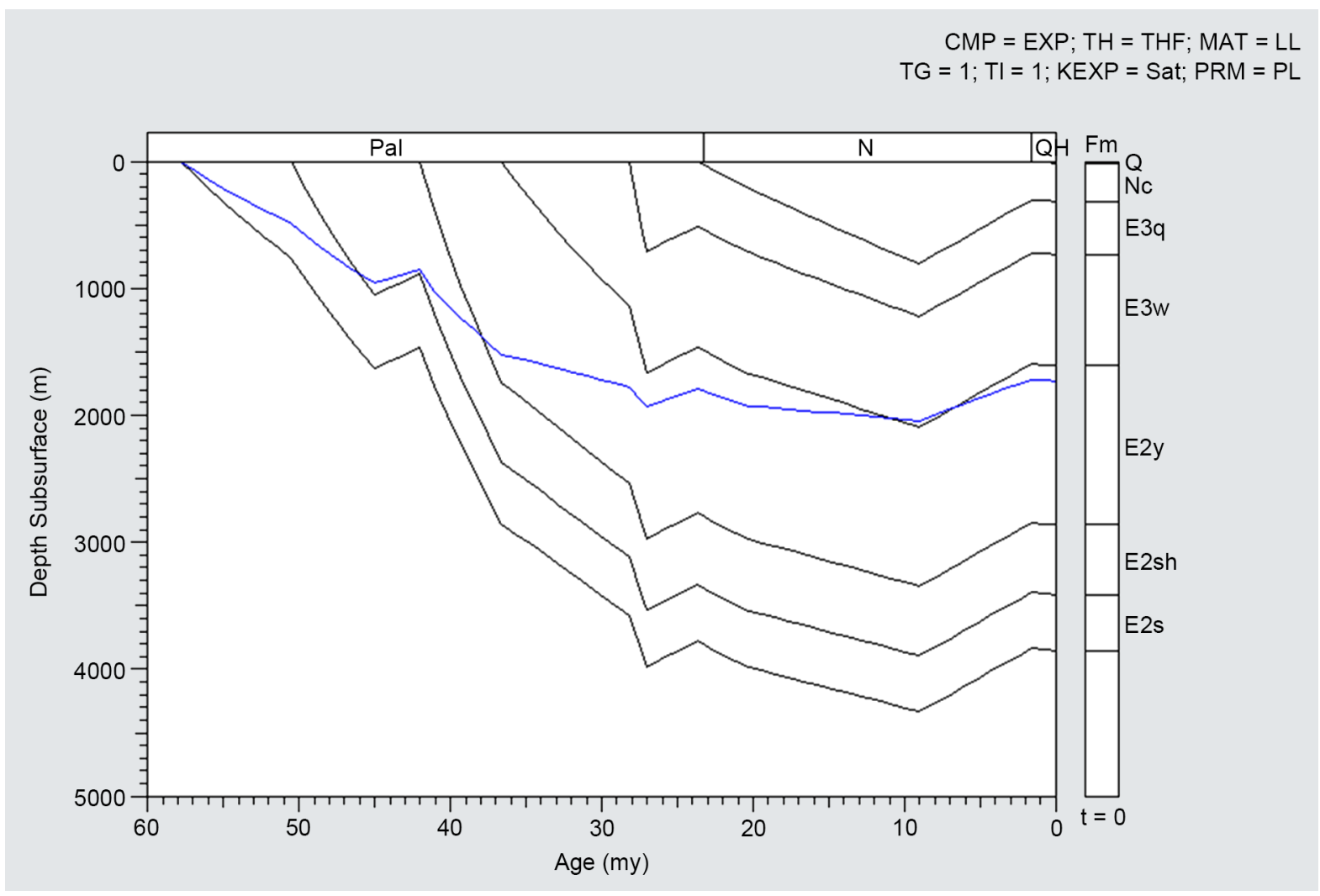

(a)

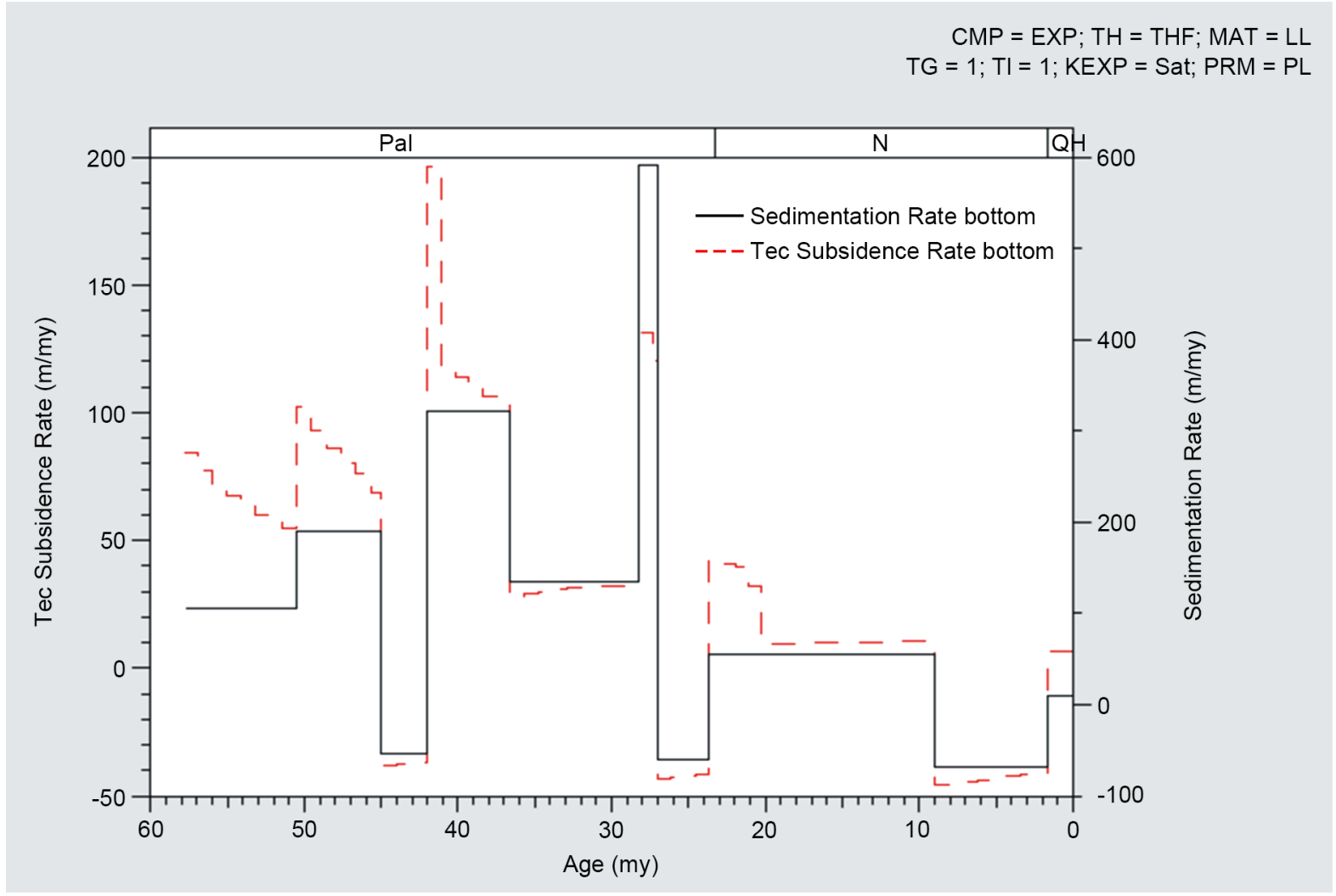

(b) 


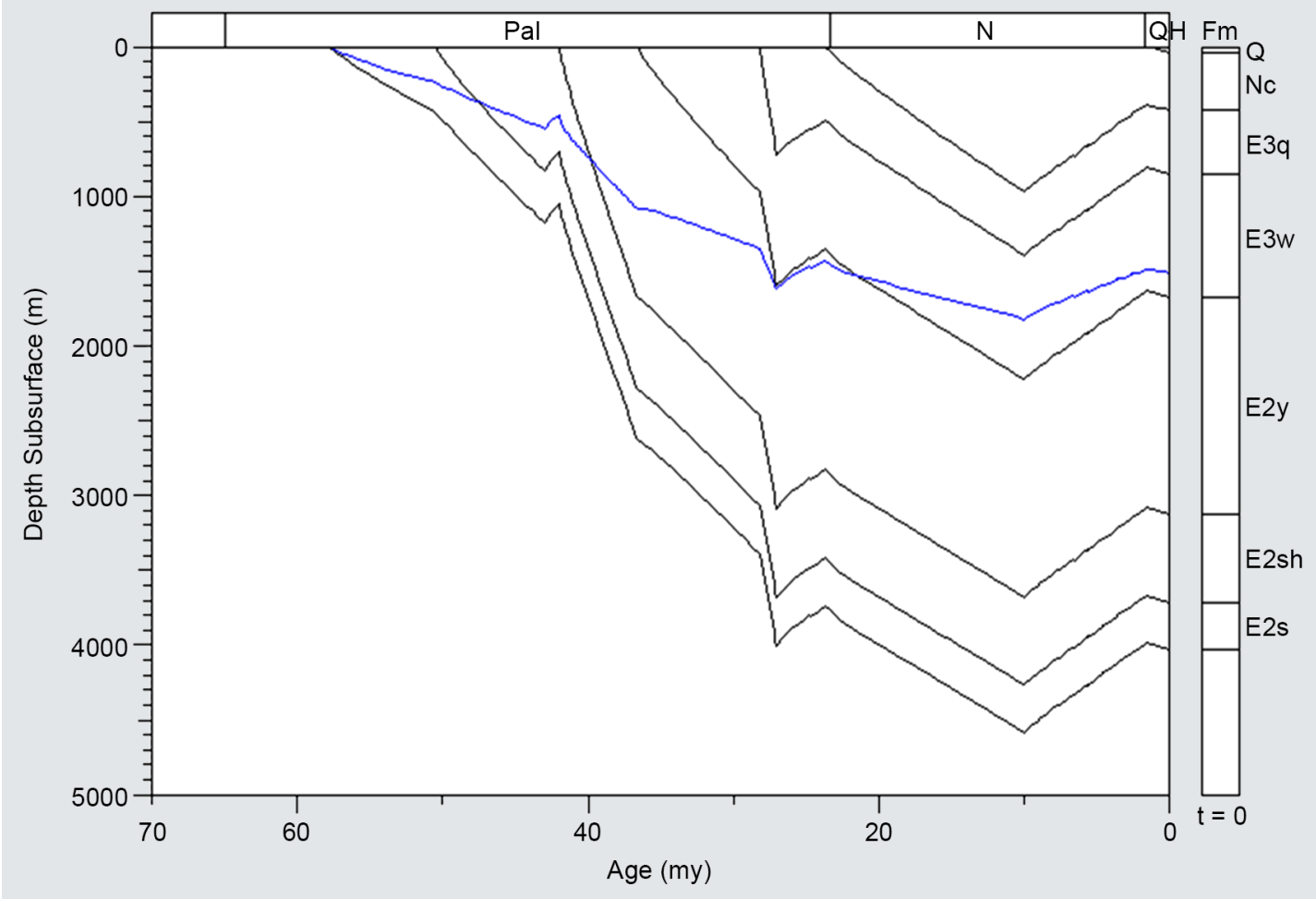

(c)

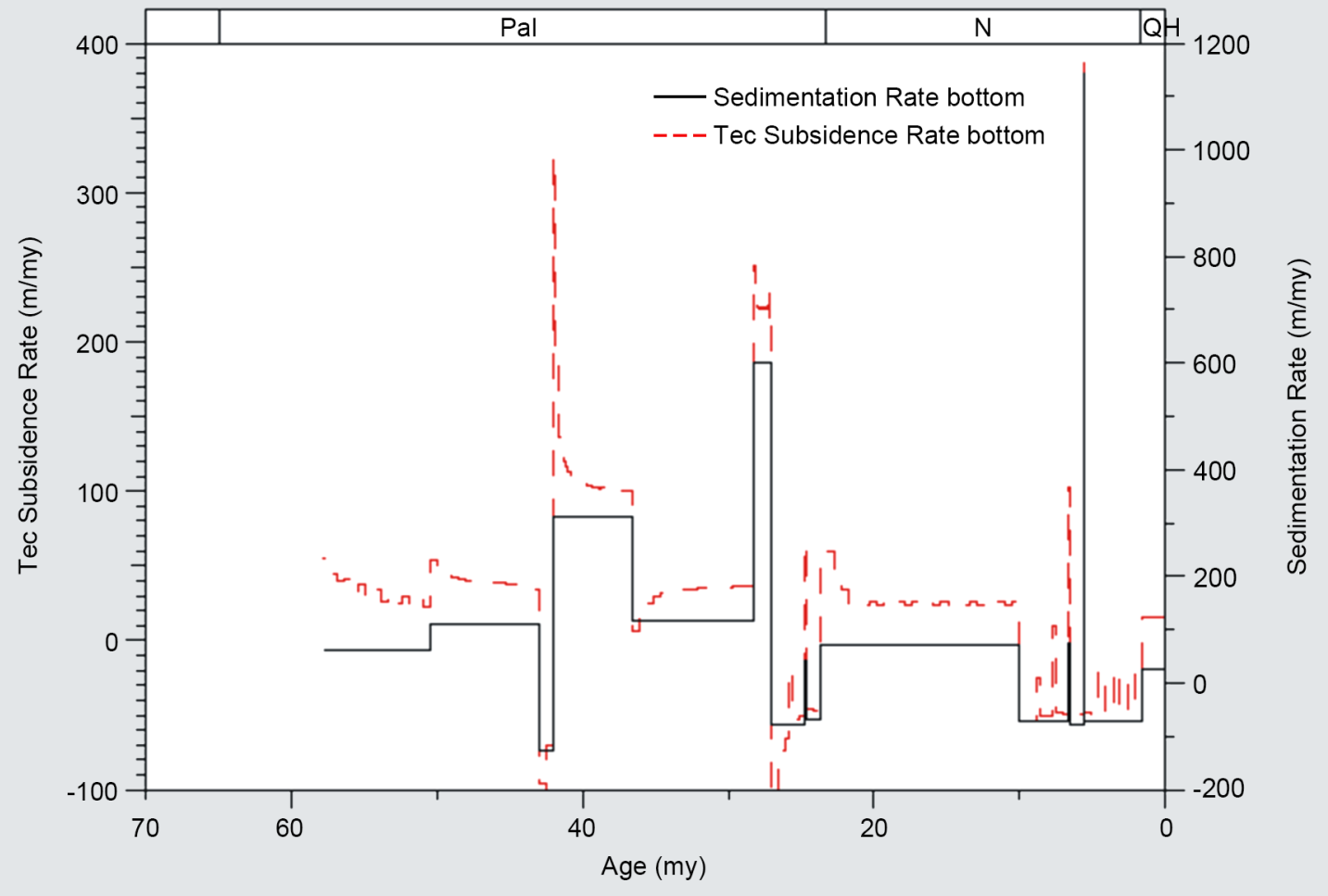

(d) 


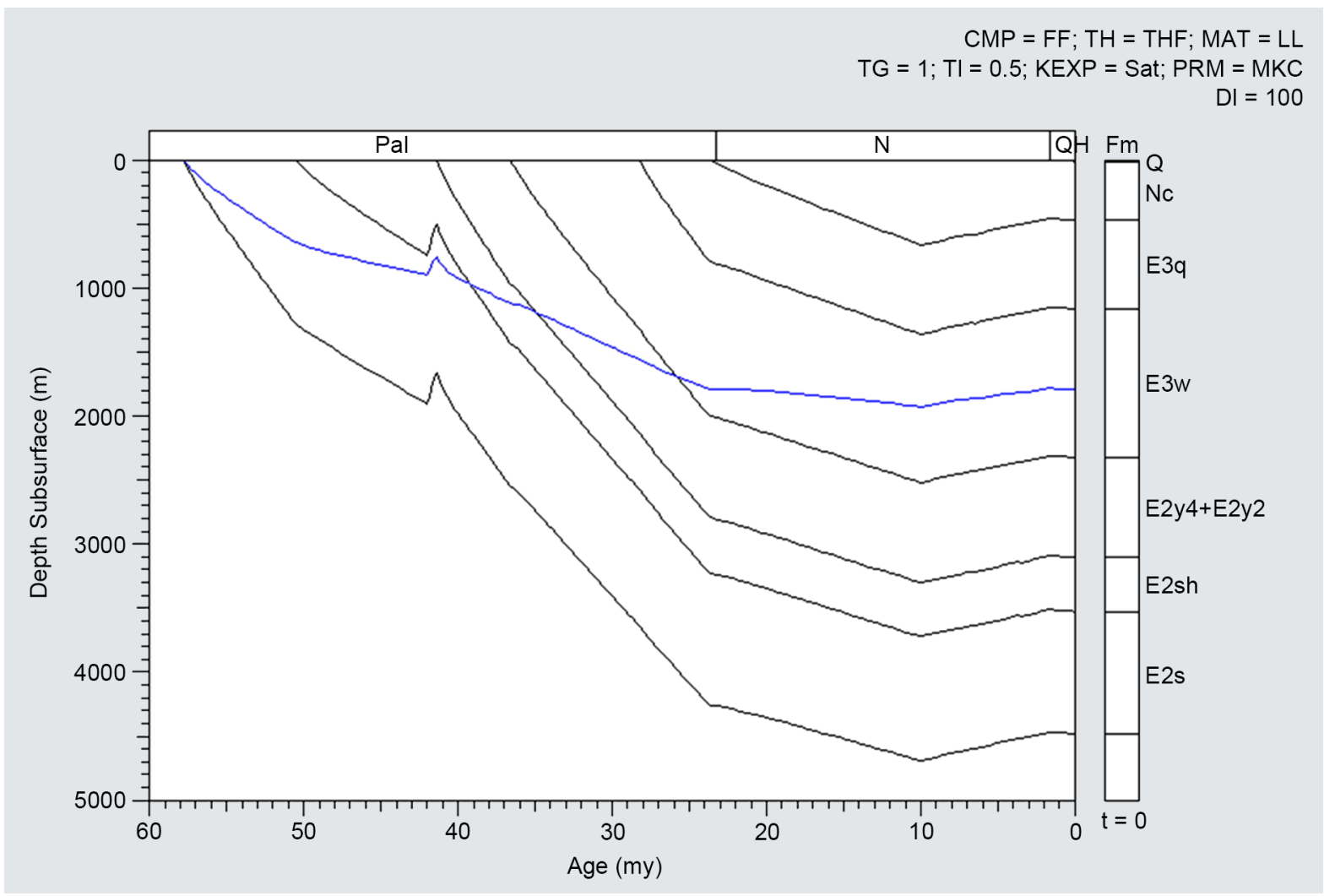

(e)

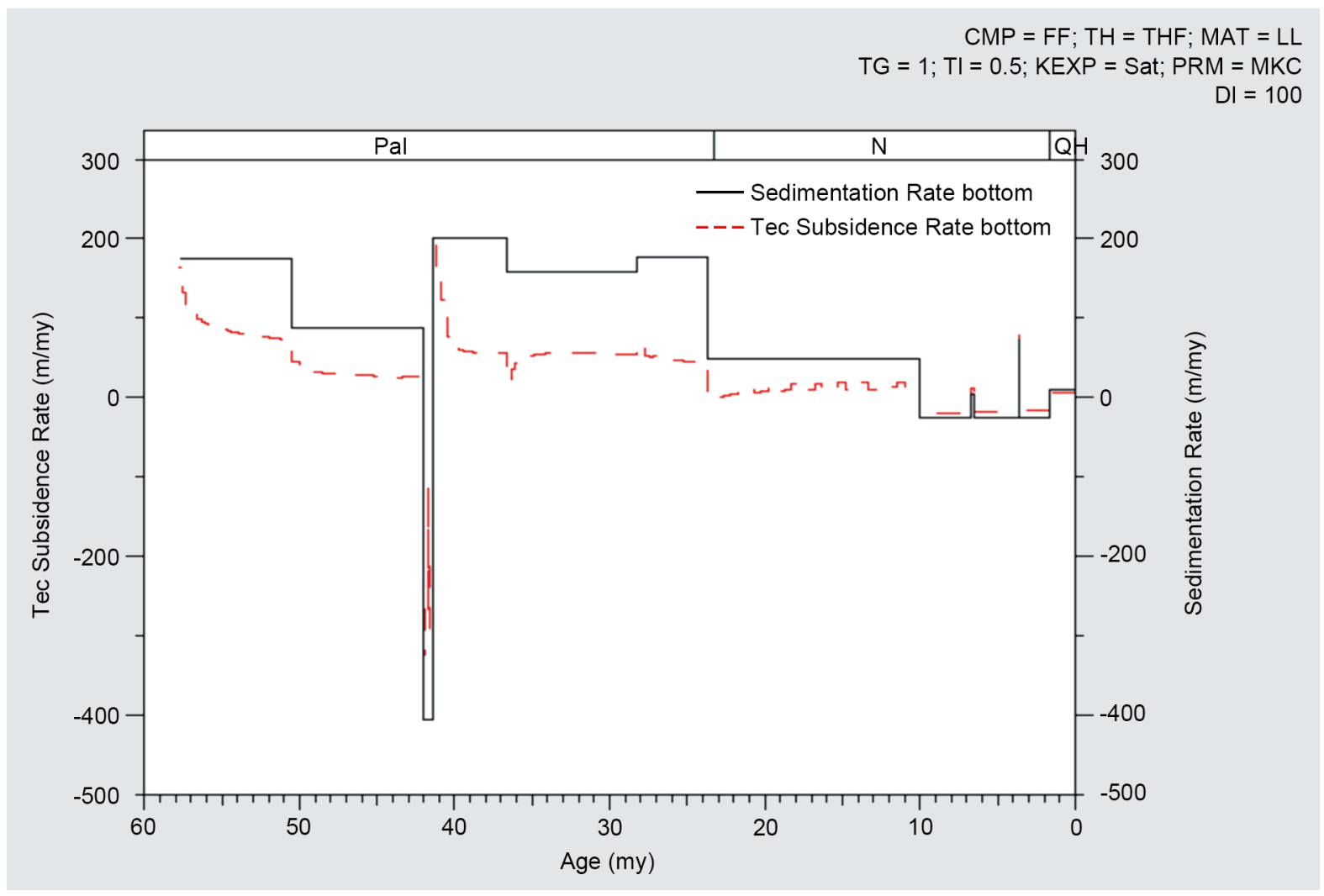

(f) 


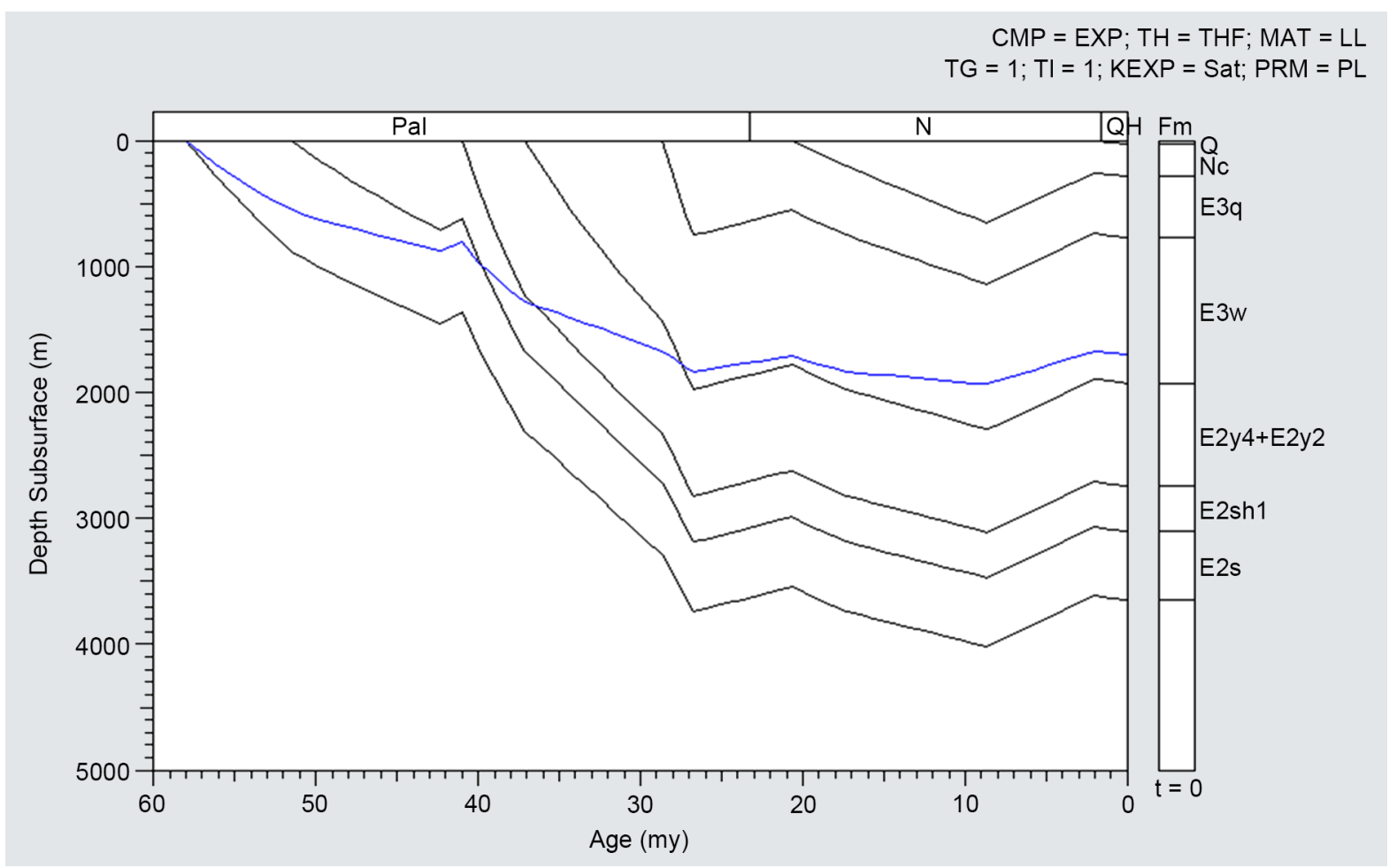

(g)

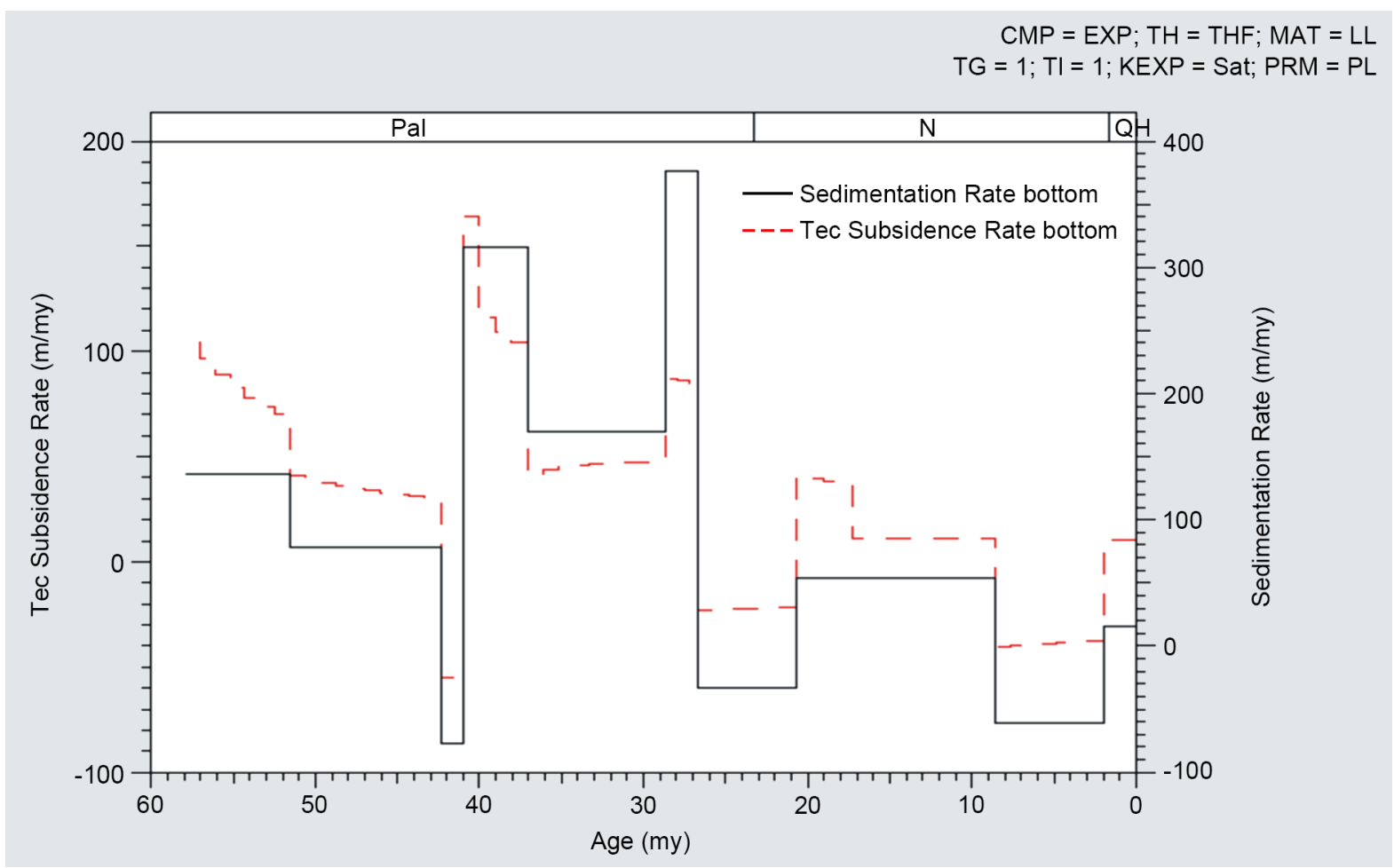

(h)

Figure 5. (a) Well Chang 7 burial history profile; (b) Well Chang 7 deposition and sedimentation rate history profile; (c) Well Chang 8 burial history profile; (d) Well Chang 8 deposition and sedimentation rate history profile; (e) Well Chang 25 burial history profile; (f) Well Chang 25 deposition and sedimentation rate history profile; (g) Well WC 1 burial history profile; (h) Well WC 1 deposition and sedimentation rate history profile. 
3) In Figure 5(g) and Figure 5(h) below, well WC1 burial curve parameters and Bo-Tai sag wells (Chang 7 and Chang 8) were constructed in accordance with the study of Wanchang formation-the burial and subsidence curve similar to the three-stage; deposition experienced three cycles of uplift and erosion during Neogene and Quaternary, Neogene and Paleogene, Yongji and sheling formations. The maximum depth is $3900 \mathrm{~m}$ and the deposition rate is consistent with the subsidence rate, but the rate of deposition and the size of the settlement are inconsistent.

In sum, the Chaluhe of Neogene sedimentary strata deposition rate decreases, the settlement curve is relatively flat, the late Neogene uplift and erosion led to the shrinking of the basin. Presently, the layer depth is not the greatest geological history depth.

\subsection{Thermal History and Maturation History}

\subsubsection{Geothermal Evolution}

The transient heat flow model (Transit Heat Flow) is used to restore the geothermal evolution of the Yitong Graben, and use the measured temperature of the simulation results to be tested and calibrated. The ancient geothermal evolutionary history of well Chang 7 for example (Figure 6(a)), it can be seen from the deposition rate and the heating rate diagram, that the heating rate and the deposition rate formation is closely related to a single well and that, the stratigraphic control of the heating rate was significantly affected by the deposition rate. In the Eocene period, rapid sedimentation in the basin at early stages, led to large deposition rate up to $570 \mathrm{~m} / \mathrm{Ma}$, the heating rate is also high, up to $42^{\circ} \mathrm{C} / \mathrm{Ma}$, larger than normal heating rate $\left(1^{\circ} \mathrm{C}-3^{\circ} \mathrm{C} / \mathrm{Ma}\right)$; subsequent Oligocene, Neogene and Quaternary sedimentation in the basin experienced a decrease in the deposition rate, with a corresponding strata heating rate decreases as result of uplift and erosion in the formation stage, the ground temperature fluctuations, shallow burial and cooling (summarized in Table 2).

In the evolutionary history of the geothermal gradient, as mentioned above, the overall performance is; since historical times, with the settling basin, filling, each faulted historical geothermal gradient decreased. In the early evolution, the basin had a high geothermal gradient, lower rate as the deposition becomes larger; late geothermal gradient value is smaller. The historical geothermal gradient is above the present geothermal gradient; apparently higher Paleo-geothermal gradient is in favor of organic matter evolution and maturation heat required for the formation of hydrocarbons. However, during basin uplift and erosion, all faulted paleomagnetic temperature gradient increased.

In the transverse direction, the geothermal gradient at different times, in different tectonic evolution of the basin with their relative value is compared. Bo-Tai sag (Figure 6(a) and Figure 6(d)) and Wanchang tectonic belt (Figure 6(d)) have relatively higher paleo-geothermal gradients and Xinanpu sag's (Figure 6(c)) geothermal gradient relatively low. The Bo-Tai sag has the highest paleo-geothermal gradient compared to the other regions. Xinanpu sag sunken has the lowest geothermal gradient and this may be from the various structural zone trap V, magmatic activity and tectonic activity intensity related differences.

\subsubsection{Organic Matter Maturation History}

On the basis of accurate restoration of the thermal history, the chemical kinetics of the LLNL-Easy\% Ro model was employed to recover mature evolution of hydrocarbons (Figure 7(a) to Figure 7(h)), and comparing the measured and simulated tests show that the method is suitable for the Chaluhe Basin, with high simulation accuracy. The simulation result shows the history of mature single wells source rocks in different tectonic units in the basins, thermal maturation evolutions are not consistent.

1) Bo-Tai sag (Well Chang 8): Eocene Shuangyang (E2s) source rocks in the early Eocene sedimentary Yongji formation about 38 Ma entered the hydrocarbon threshold (Ro $=0.5 \%)$ (Figure 7(c) and Figure 7(d)), and at Oligocene sedimentary Wanchang about 31 Ma generate large quantities of oil (Ro $=0.7 \%-1.0 \%$ ), and is still at this stage; Eocene Sheling group (E2sh) source rocks in the late Eocene sedimentary, Yongji formation

Table 2. Measured geothermal temperature from wells (compared to well simulations).

\begin{tabular}{ccccccccccccc}
\hline Well & Chang 7 & \multicolumn{4}{c}{ Chang 8} & & \multicolumn{2}{c}{ WC 1 } & Chang 25 \\
Depth (m) & 7 & 2820 & 3427.6 & 3755.1 & 3813.6 & 2402.5 & 2836.5 & 3485.5 & 3505 & 3796.5 & 3882.3 & 4131.3 \\
Geothermal $\left({ }^{\circ} \mathrm{C}\right)$ & 94.44 & 105.5 & 133.89 & 145.6 & 147.22 & 90 & 106.7 & 132.2 & 131.11 & 147.22 & 149 & 151.11 \\
\hline
\end{tabular}




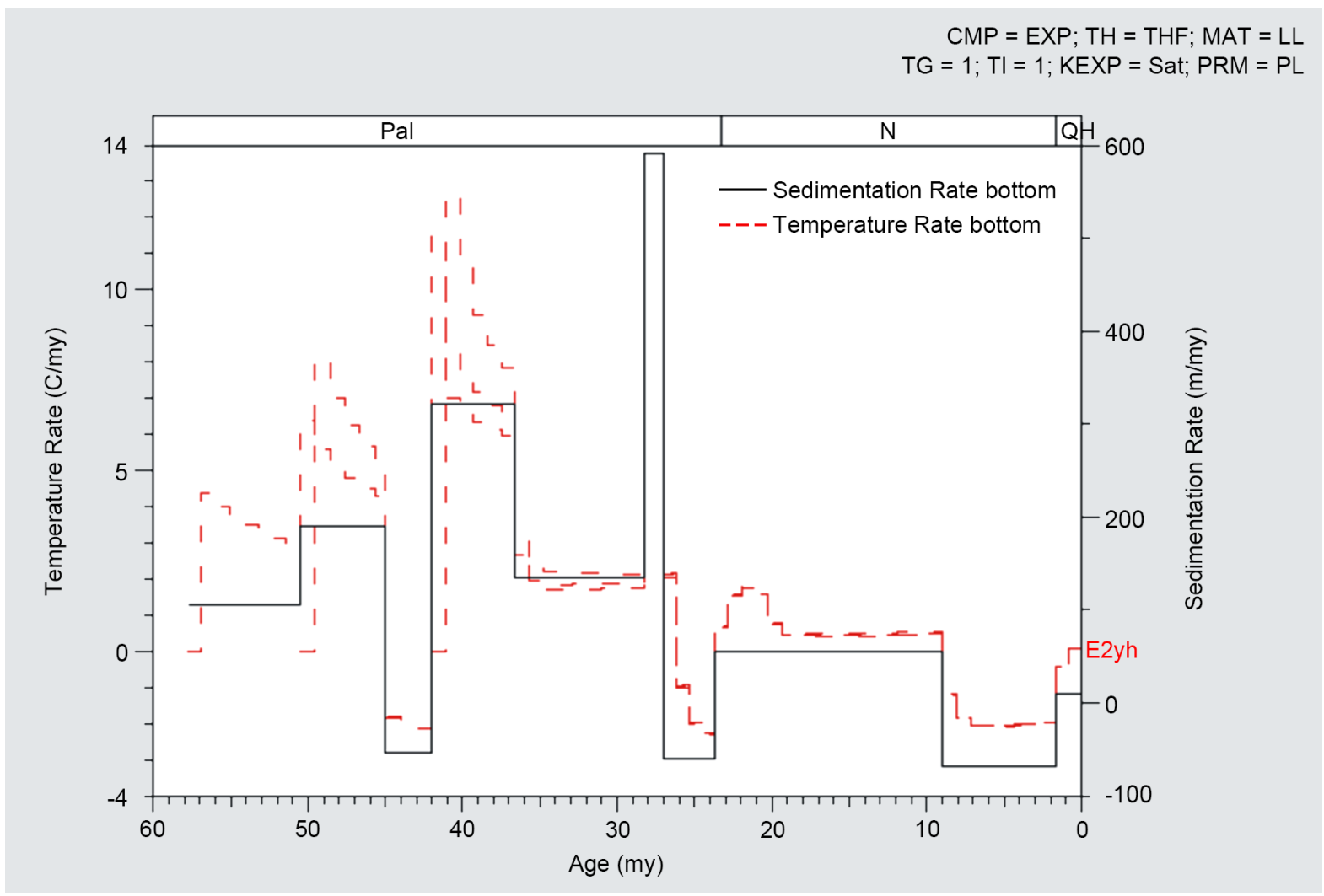

(a)

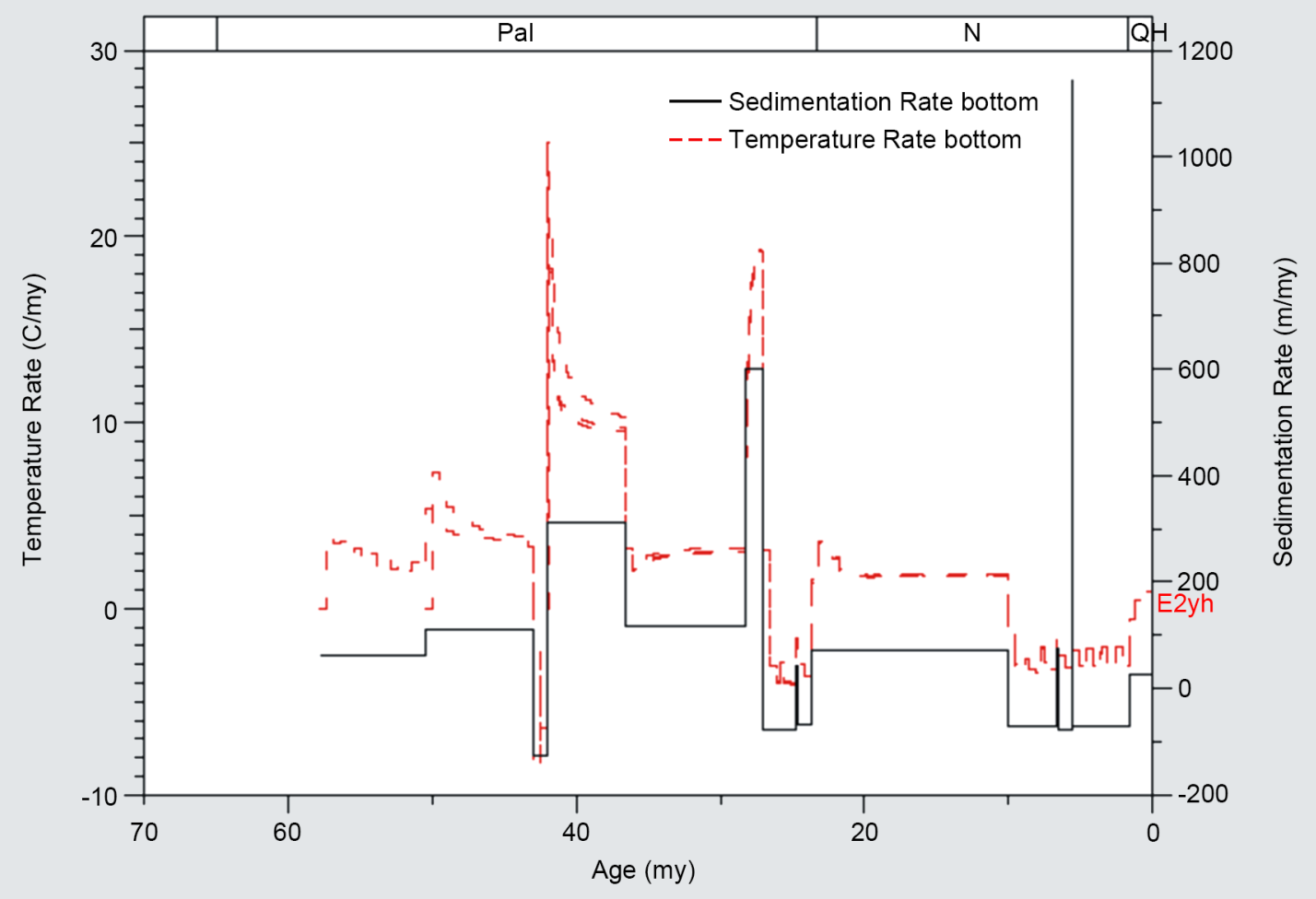

(b) 


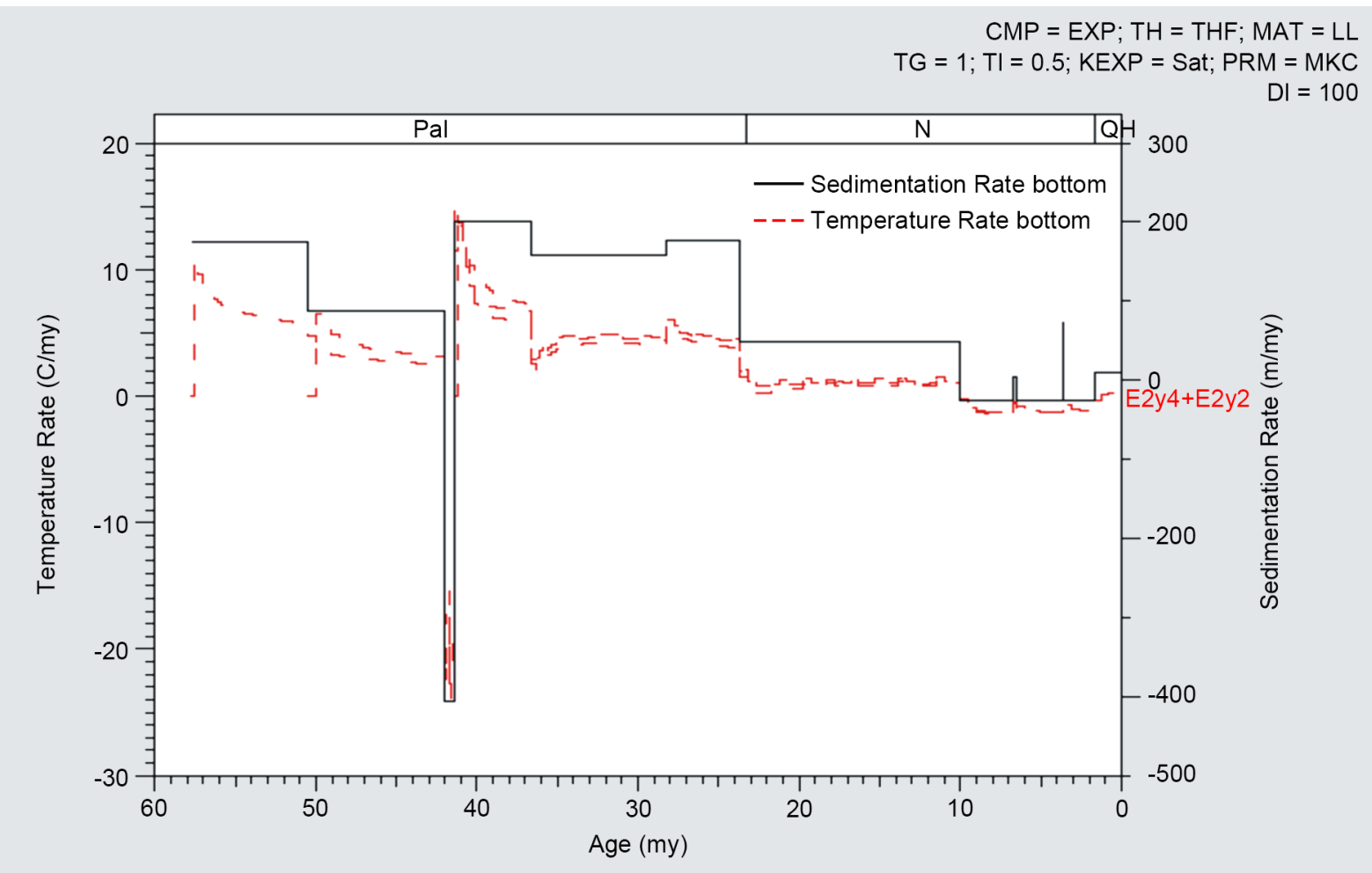

(c)

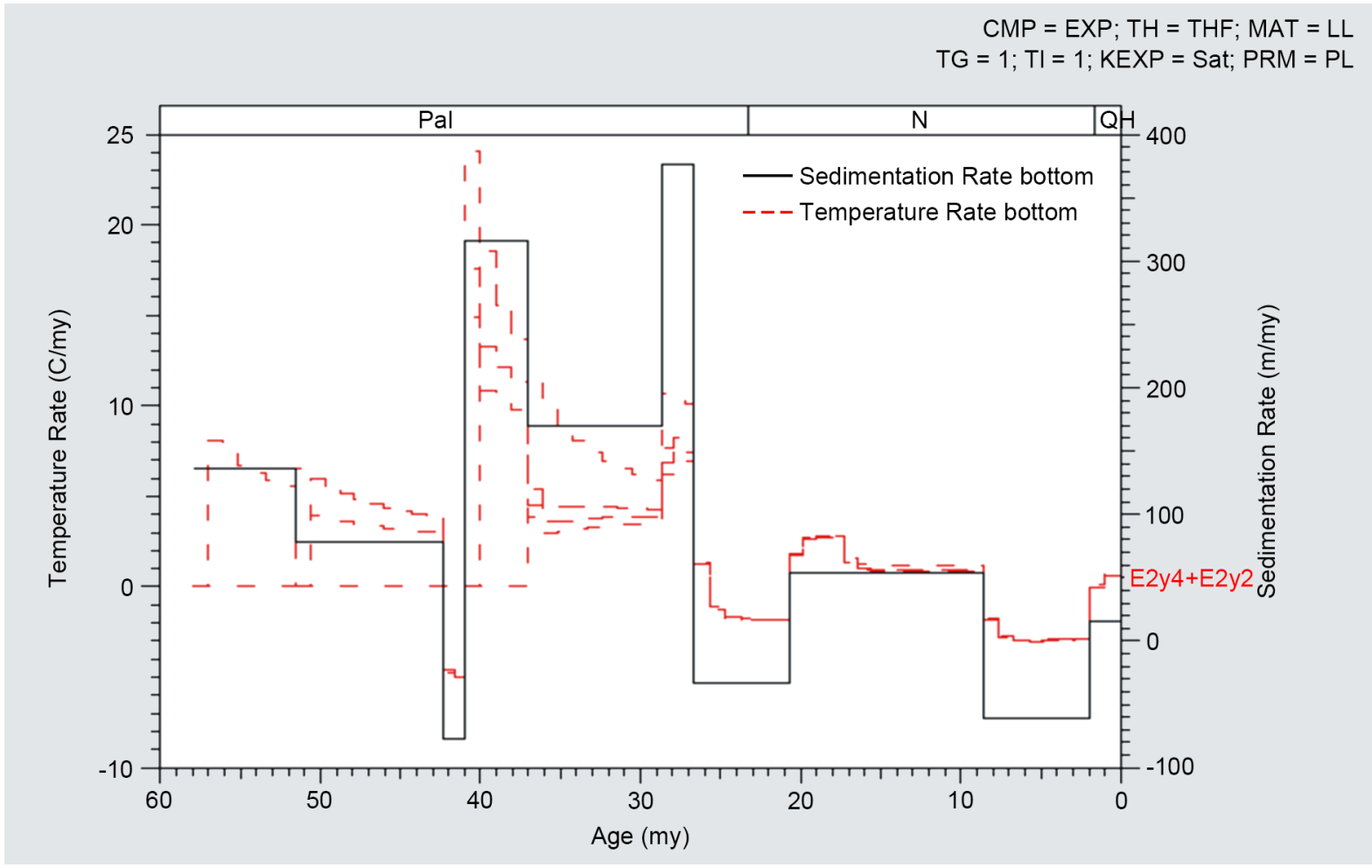

(d)

Figure 6. (a) Well Chang 7 temperature evolution as a result deposition rate profile; (b) Well Chang 8 temperature evolution as a result deposition rate profile; (c) Well Chang 25 temperature evolutions as a result deposition rate profile; (d) Well WC 1 temperature evolutions as a result deposition rate profile. 


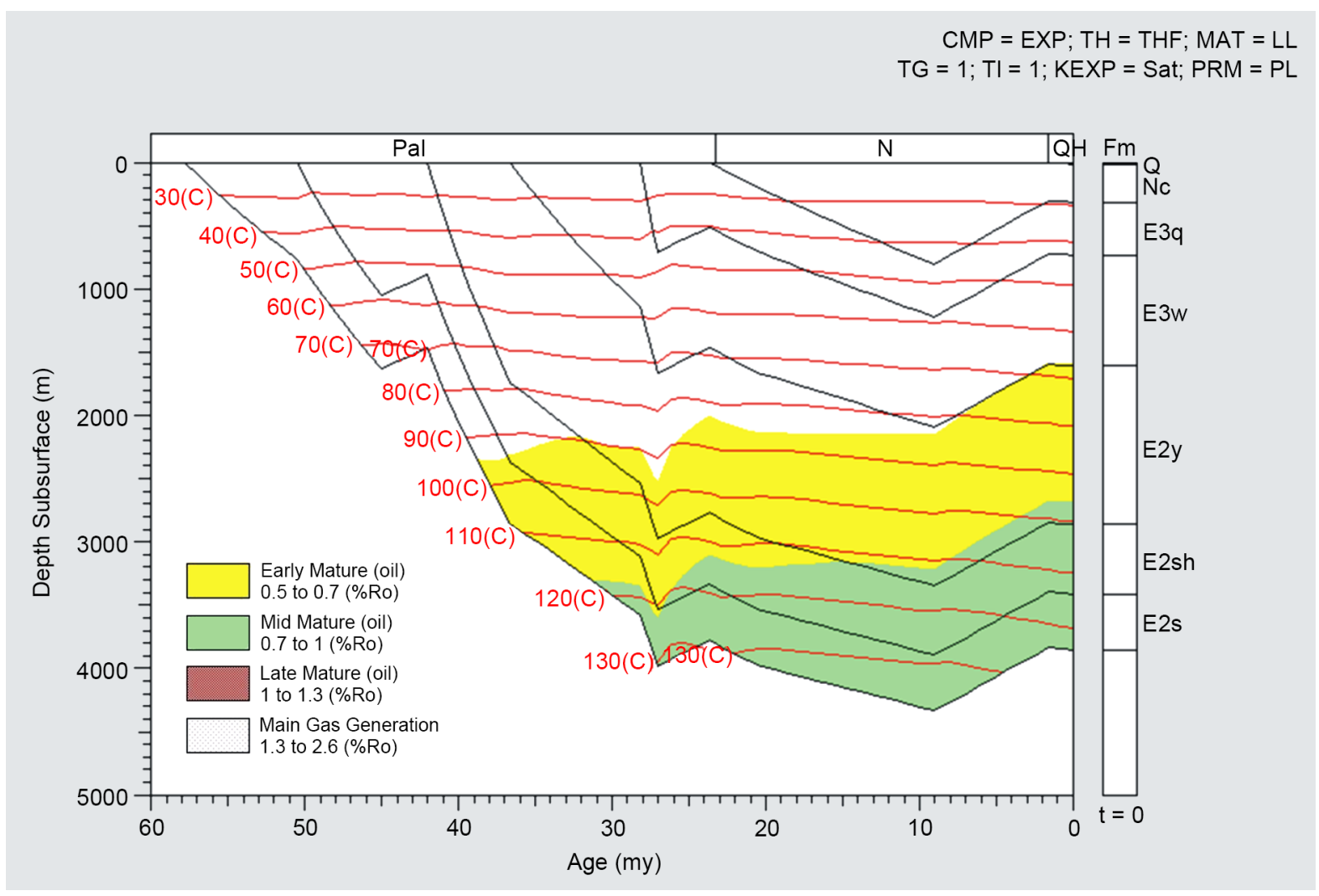

(a)

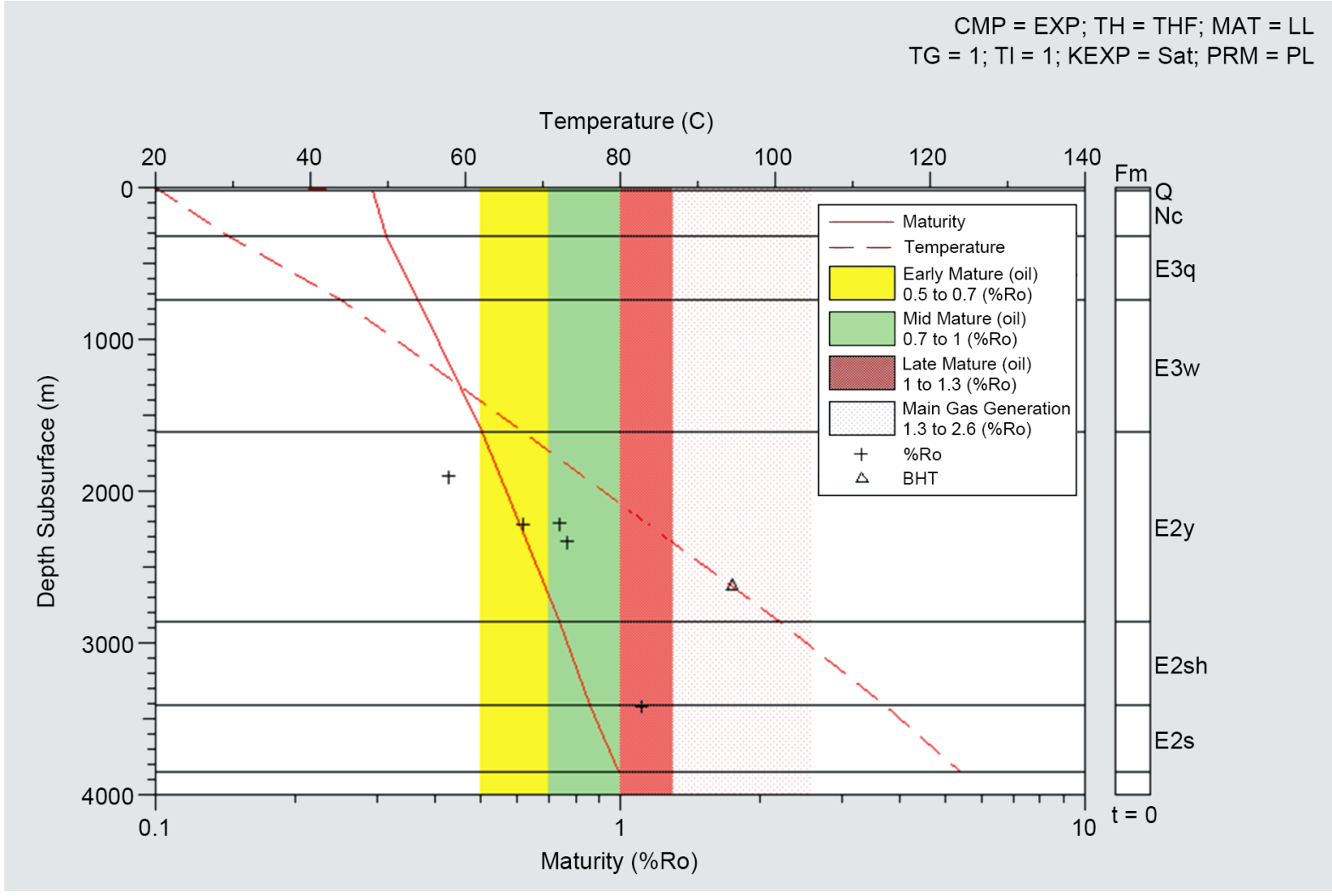

(b) 


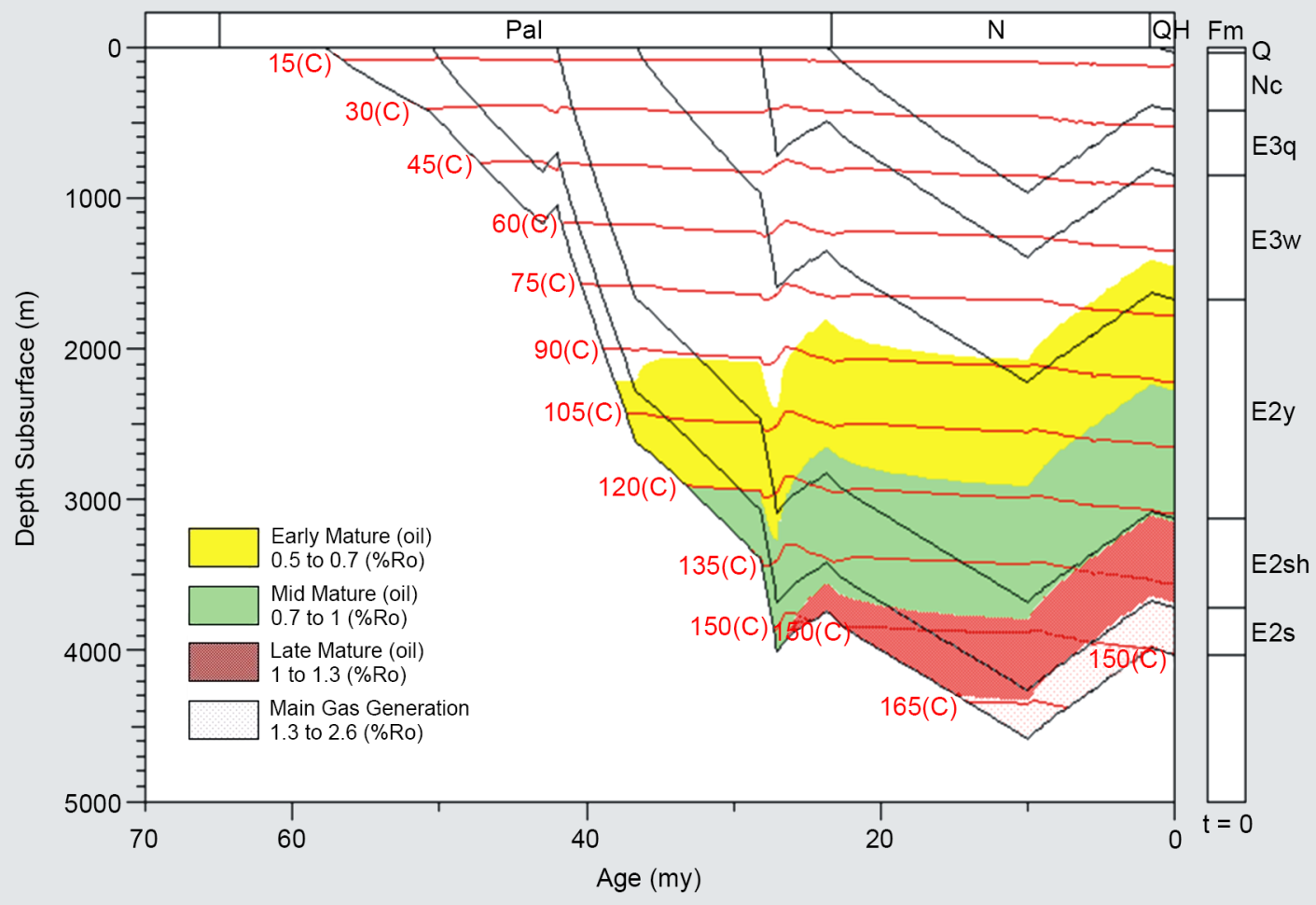

(c)

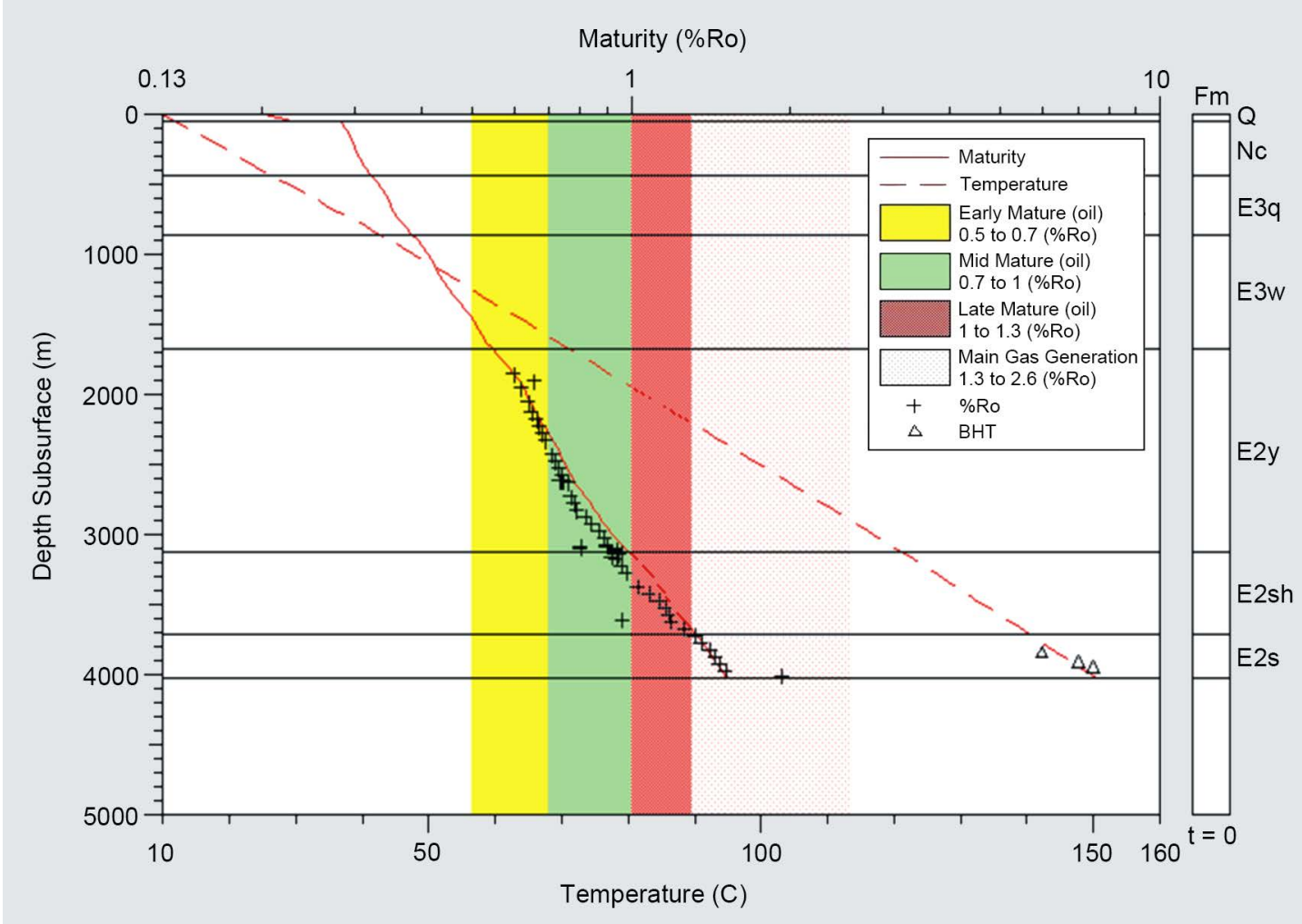

(d) 


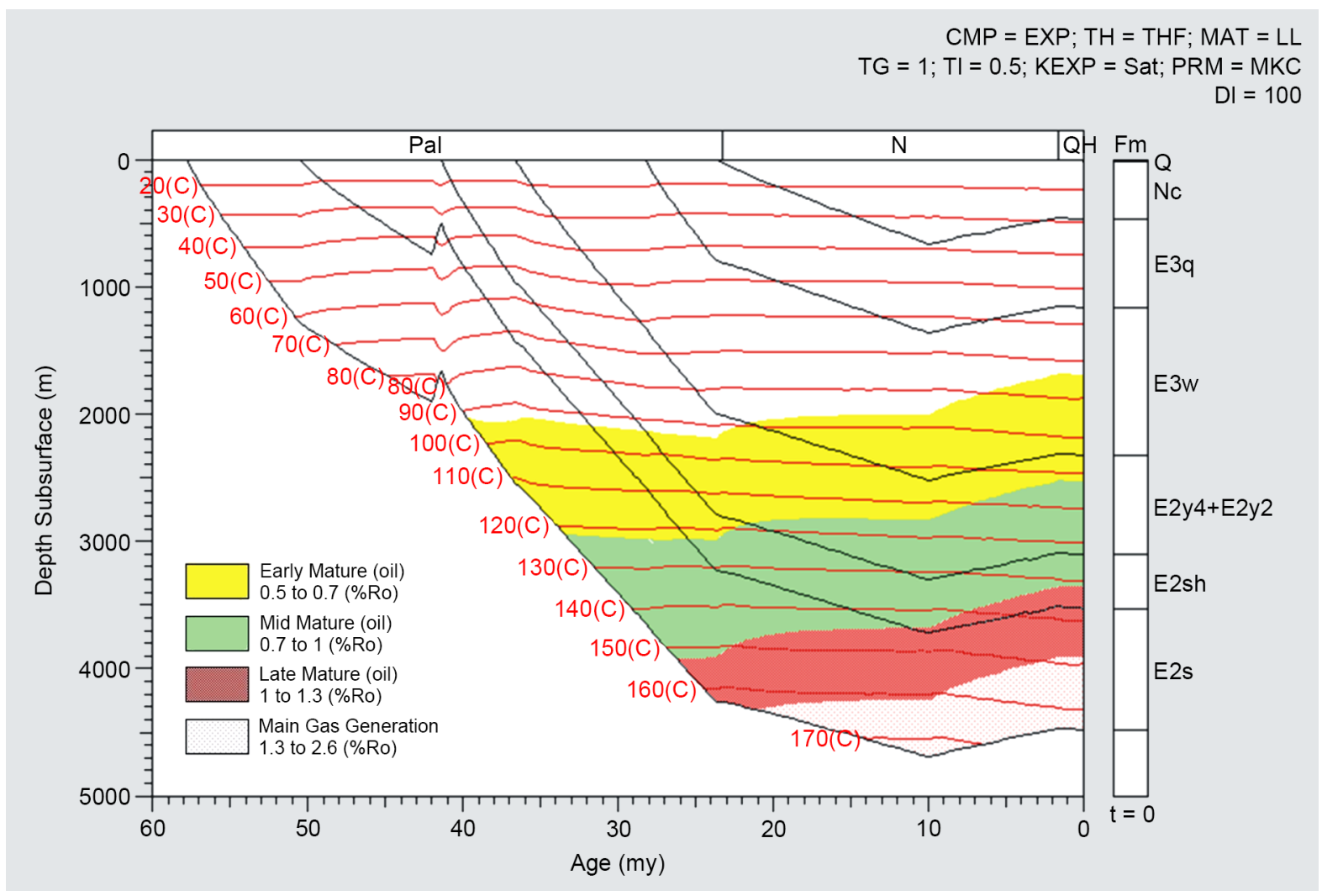

(e)

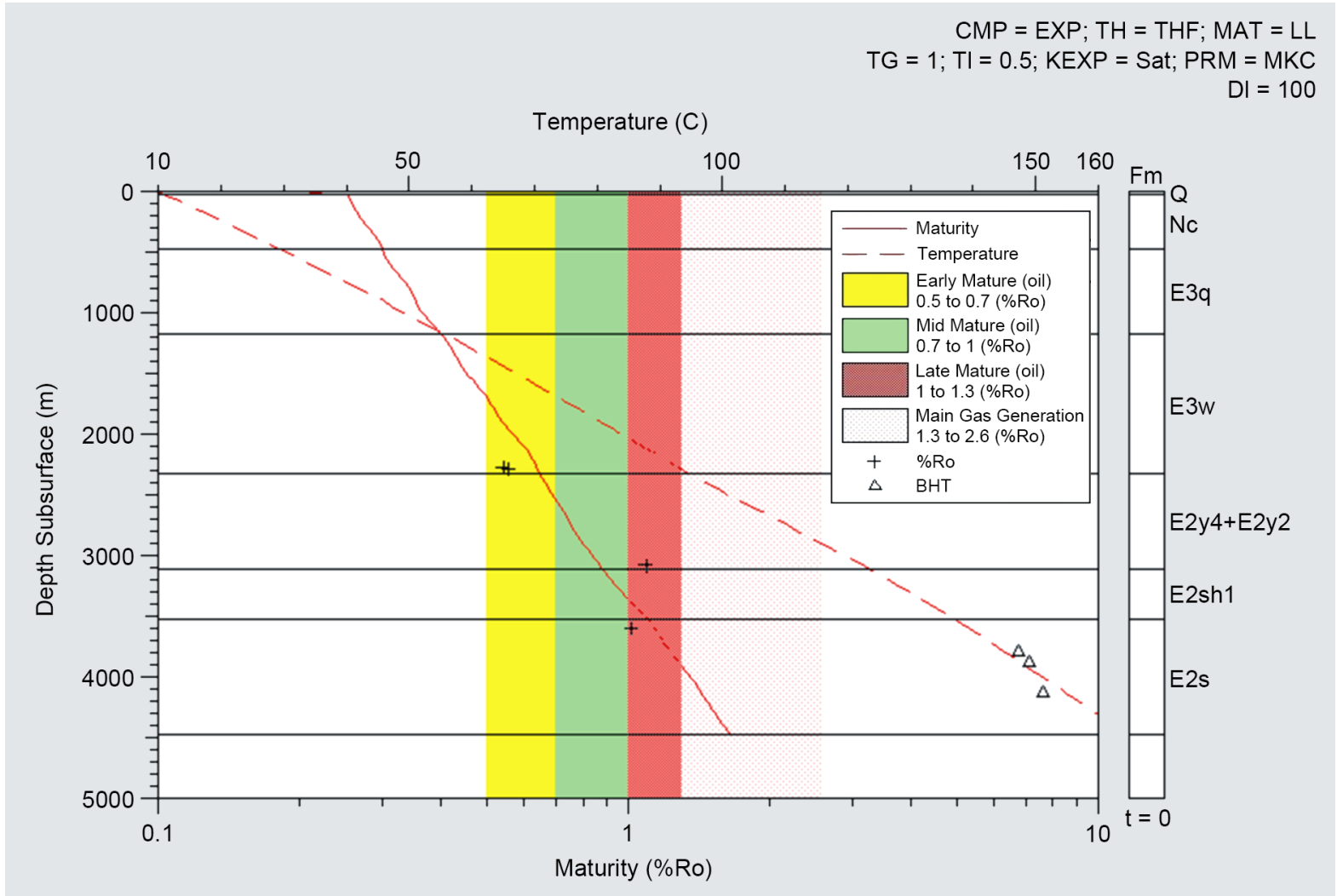

(f) 


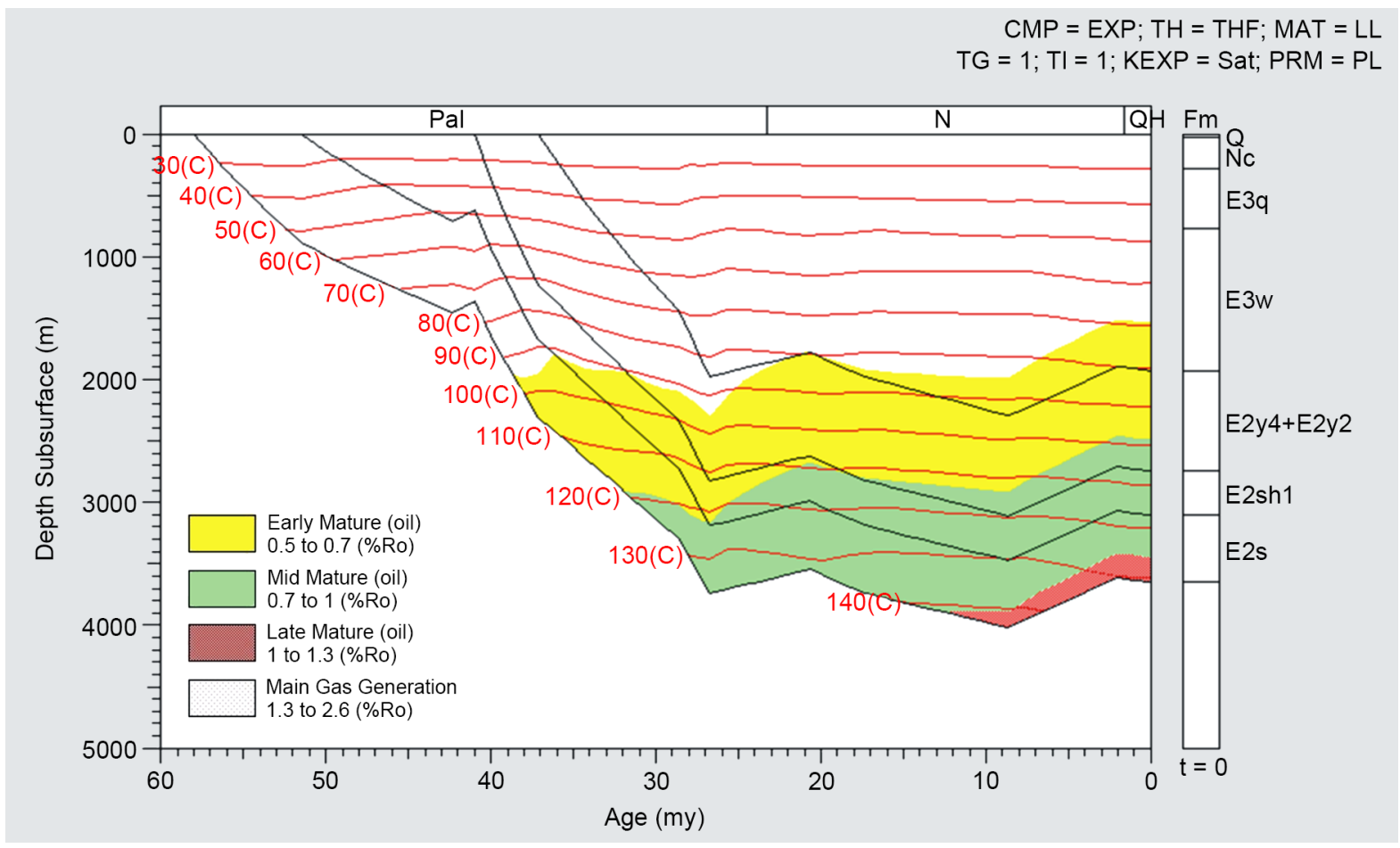

(g)

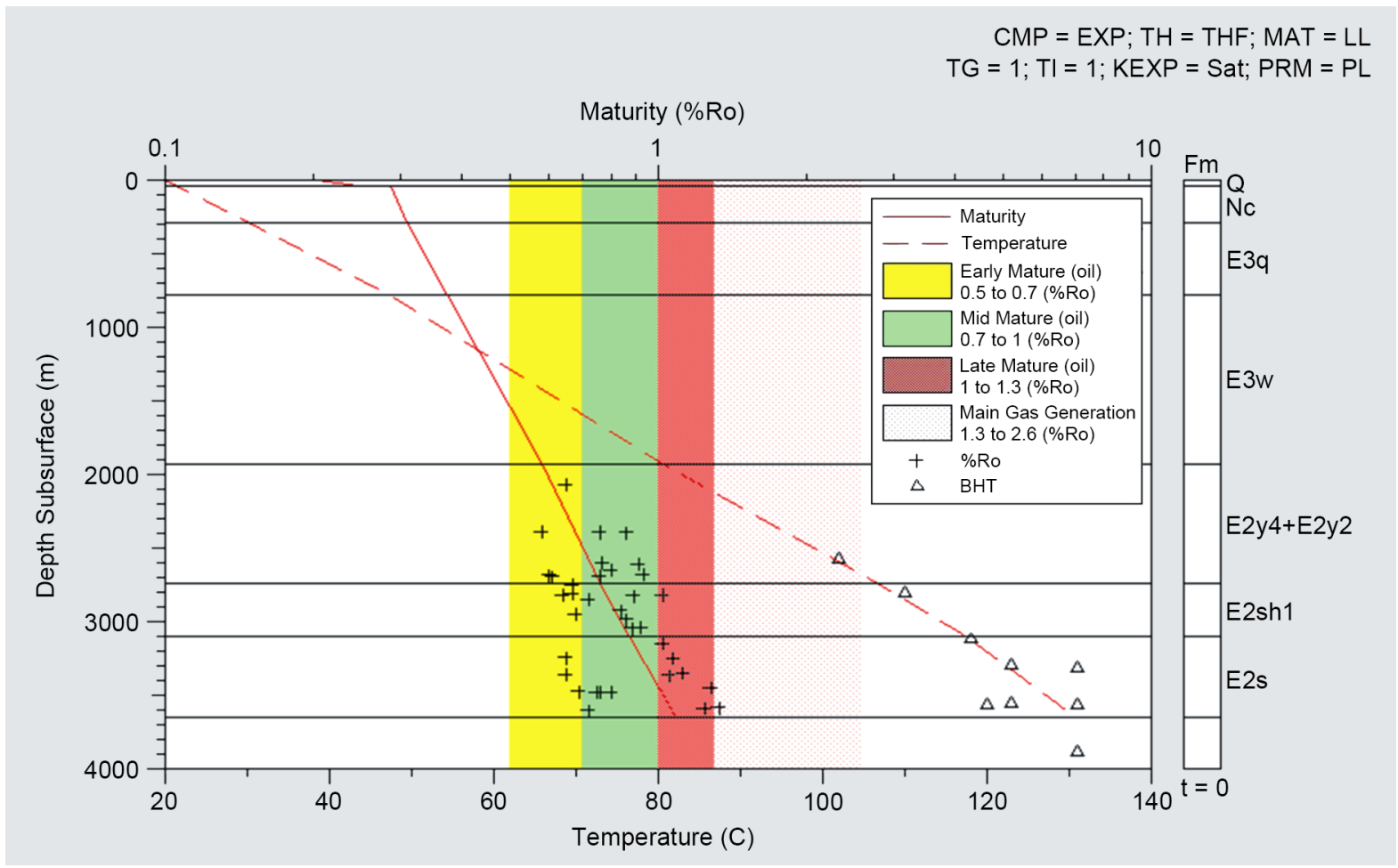

(h)

Figure 7. (a) Well Chang 7 simulated thermal maturation history profile; (b) Well Chang 7 measured geothermal maturity profile (compared with simulated); (c) Well Chang 8 simulated thermal maturation history profile; (d) Well Chang 8 measured geothermal maturity profile (compared with simulated); (e) Well Chang 25 simulated thermal maturation history profile; (f) Well Chang 25 measured geothermal maturity profile (compared with simulated); (g) Well WC 1 simulated thermal maturation history profile; (h) Well WC 1 measured geothermal maturity profile (compared with simulated). 
about 36 Ma entered into the hydrocarbon threshold; Oligocene sedimentary Wanchang about 27 Ma entering the final stages of a large quantities of oil generation, Eocene Yongji formation (E2y) source rocks in the sedimentary entered the hydrocarbon threshold in the early Oligocene about $31 \mathrm{Ma}$; Neogene Chaluhe strata in the upper sedimentary approximately $15 \mathrm{Ma}$ is also at its oil generation stage and is still at this stage, while the lower strata is not into oil generation but still in biogenic gas phase.

2) Xinanpu sag of the Chaluhe basin (Well Chang 25): Eocene Shuangyang (E2s) source rocks in the Eocene Yongji formation early deposition about 40 Ma entered the hydrocarbon threshold (Figure 7(e) and Figure 7(f)), Oligocene sedimentary Wanchang, about $34 \mathrm{Ma}$ is at early oil generation stage, early Neogene sedimentary Chaluhe of about 21 Ma entered into gas threshold, presently at the bottom of the dry gas generation stage, gas is still in the upper stage; Eocene sheling group (E2sh) source rock in the mid-Eocene sedimentary Yongji formation about 32 Ma entered the hydrocarbon threshold, and at Oligocene sedimentary approximately the mid of 25 Ma entered the peak oil generation stage, then late gas threshold at about 10 Ma during the Neogene Chaluhe formation and presently the bottom of the source rock is still at this stage, and the source rocks in the upper part are in peak oil generation stage; Eocene Yongji formation (E2y) source rocks in the Oligocene Wanchang sedimentary about 29 Ma entered the final hydrocarbon threshold and at Neogene Chaluhe about 21 Ma generated a lot of oil at the early stage and presently still in that stage.

3) Wanchang structural belt (Well WC 1): Eocene Shuangyang (E2s) source rocks and the early Eocene Yongji sedimentary formation about 38 Ma entered the hydrocarbon threshold (Figure 7(g) and Figure 7(h)), and during the Oligocene Wanchang sedimentary and early Yongji formation about 32 Ma entered the final stage of peak oil generation and the early gas threshold in the Neogene Chaluhe about 12 Ma period, the lower part is still in a lot of oil generation stage; Eocene Sheling group (E2sh) source rocks about 36 Ma is into the hydrocarbon threshold and during Oligocene Wanchang and late Neogene Chaluhe about 26 Ma entered the final phase of oil generation stage, and presently still at this stage; Eocene Yongji formation (E2y) source rocks deposited early in the formation of about $31 \mathrm{Ma}$ is into hydrocarbon threshold, and the upper strata in the Neogene Chaluhe sedimentary approximately 19 Ma still has a lot of time before entering the oil generation stage, and prospects are still at this stage now, but still in the lower part of the formation of biogenic gas phase.

In summary, the Eocene formation source rocks in the Bo-Tai sag (Wells Chang 7 and Chang 8) has varying degrees of thermal evolution in different regions. Eocene Shuangyang and Sheling source rocks presently have reached a mature stage of oil production and above (Ro > 0.7\%). Eocene overlying Yongji formation source rocks has entered a mature hydrocarbon threshold; Xinanpu sag's (Well Chang 25) lower Eocene Shuangyang source rocks have reached the present gas generation phase, Shuangyang upper and lower part Sheling source rocks are into the mature stage of oil generation, and a lot of upper Sheling and Yongji formation source rocks have reached middle mature stage.

\section{Summary and Conclusions}

The summary of results interpretation and findings as discussed above of the one Dimensional (1D) Oil and Gas Generated/Expelled is undertaken for all four wells: Chang 7, 8, 25 and WC 1. The main focus as per the objectives set out in this study would do a summary of formations that contain the main hydrocarbon kitchen.

\subsection{Summary}

\subsubsection{Present Day Oil Generated}

As per Table 3, the highest quantities of Oil Generated from Shuangyang source units presently is within Well Chang 8 and 25; 35.85 mg/g TOC and 39.49 mg/g TOC respectively. Presently, the Shuangyang source units generate oil more than the Sheling source units in all the wells under this study.

Table 3. Present day oil generated.

\begin{tabular}{cccccccccccccc}
\hline Well No. & \multicolumn{3}{c}{ Chang 7 } & \multicolumn{3}{c}{ Chang 8} & \multicolumn{3}{c}{ WC1 } & \multicolumn{3}{c}{ Chang 25 } \\
\hline Horizons & $\mathrm{E}_{2} \mathrm{~S}$ & $\mathrm{E}_{2} \mathrm{sh}$ & $\mathrm{E}_{2} \mathrm{y}$ & $\mathrm{E}_{2} \mathrm{~S}$ & $\mathrm{E}_{2} \mathrm{sh}$ & $\mathrm{E}_{2} \mathrm{y}$ & $\mathrm{E}_{2} \mathrm{~S}$ & $\mathrm{E}_{2} \mathrm{sh}$ & $\mathrm{E}_{2} \mathrm{y}$ & $\mathrm{E}_{2} \mathrm{~S}$ & $\mathrm{E}_{2} \mathrm{sh}$ & $\mathrm{E}_{2} \mathrm{y}$ \\
\hline $\mathrm{G}_{\text {oil }}(\mathrm{mg} / \mathrm{g}$ TOC$)$ & 27.39 & 14.7 & 5.03 & 35.85 & 29.8 & 11.39 & 22.69 & 10.02 & 3.15 & 39.49 & 27.05 & 14.92 \\
$\mathrm{G}_{\text {time }}(\mathrm{Ma})$ & 36.11 & 31.66 & 26.35 & 38.07 & 35.61 & 28.2 & 34.87 & 30.42 & 26.2 & 41.4 & 32.15 & 28.69 \\
\hline
\end{tabular}




\subsubsection{Present Day Gas Generated}

Deducting from Table 4 below, Shuangyang formation in Well Chang 25 generates much quantity of Gas at present, $92.83 \mathrm{mg} / \mathrm{g}$ TOC more than its Sheling and Yongji counterpart. Sheling formation in Wells Chang 7, 8 and 25 also produce substantial amounts of Gas with Well WC 1 located on the Wanchang structural belt of the basin, generating the least Gas quantity.

\subsubsection{Present Day Oil Expelled}

Presently, there is no Oil expelled from the Eocene Yongji formation source units into traps of reservoirs of all the four Wells considered in this study. The Shuangyang formation has the highest Oil expelled from all Wells under the study area with Well Chang 8 been the highest followed by Wells Chang 25, 7 and WC 1 in that order as per the Table 5 below.

\subsubsection{Present Day Gas Expelled}

Well Chang 25 Lower Eocene Shuangyang formation in the Xinanpu sag within the Chaluhe basin which remains the main and only source unit presently records the highest expulsion of $72 \mathrm{mg} / \mathrm{g}$ TOC followed by Well Chang 8, 7 and WC 1 source units $64.26 \mathrm{mg} / \mathrm{g}$ TOC, $46.17 \mathrm{mg} / \mathrm{g}$ TOC and $22.02 \mathrm{mg} / \mathrm{g}$ TOC respectively as per Table 6.

\subsection{Conclusions}

Wells maturity data showed that most or the entire source rocks buried below $2000 \mathrm{~m}$ within all the seismic regions analyzed in this study are matured.

Fortunately, all of the oil generated in these wells is expelled into the silty mudstone dominated reservoirs in the Eocene Shuangyang formation but Gas was not generated and expelled from some of the source units in the study area of some of the wells. This may not be the situation entirely within the whole study area since prevalent geological conditions may differ slightly from place to place.

Finally, it is recommended that, source units with high generation and expulsion rates and quantities could have their reservoirs exploited for these hydrocarbons by drilling of wells in these reservoirs.

Table 4. Present day gas generated.

\begin{tabular}{ccccccccccccccc}
\hline Well No. & \multicolumn{3}{c}{ Chang 7 } & \multicolumn{3}{c}{ Chang 8 } & \multicolumn{3}{c}{ WC1 } & \multicolumn{4}{c}{ Chang 25 } \\
\hline Horizons & $\mathrm{E}_{2} \mathrm{~S}$ & $\mathrm{E}_{2} \mathrm{sh}$ & $\mathrm{E}_{2} \mathrm{y}$ & $\mathrm{E}_{2} \mathrm{~S}$ & $\mathrm{E}_{2} \mathrm{sh}$ & $\mathrm{E}_{2} \mathrm{y}$ & $\mathrm{E}_{2} \mathrm{~S}$ & $\mathrm{E}_{2} \mathrm{sh}$ & $\mathrm{E}_{2} \mathrm{y}$ & $\mathrm{E}_{2} \mathrm{~s}$ & $\mathrm{E}_{2} \mathrm{sh}$ & $\mathrm{E}_{2} \mathrm{y}$ \\
\hline $\mathrm{G}_{\mathrm{gas}}(\mathrm{mg} / \mathrm{g}$ TOC$)$ & 61.22 & 31.73 & 11.68 & 80.25 & 65.75 & 25.88 & 50.48 & 22.96 & 6.98 & 92.83 & 60.43 & 32.93 \\
$\mathrm{G}_{\text {time }}(\mathrm{Ma})$ & 36.11 & 31.66 & 26.35 & 38.07 & 35.61 & 28.2 & 34.87 & 30.42 & 26.2 & 41.4 & 32.15 & 28.69 \\
\hline
\end{tabular}

Table 5. Present day oil expelled for all wells.

\begin{tabular}{|c|c|c|c|c|c|c|c|c|c|c|c|c|}
\hline \multirow{2}{*}{$\begin{array}{l}\text { Well No. } \\
\text { Horizons }\end{array}$} & \multicolumn{3}{|c|}{ Chang 7} & \multicolumn{3}{|c|}{ Chang 8} & \multicolumn{3}{|c|}{ WC1 } & \multicolumn{3}{|c|}{ Chang 25} \\
\hline & $\mathrm{E}_{2} \mathrm{~S}$ & $\mathrm{E}_{2} \mathrm{sh}$ & $\mathrm{E}_{2} \mathrm{y}$ & $\mathrm{E}_{2} \mathrm{~S}$ & $\mathrm{E}_{2} \mathrm{sh}$ & $\mathrm{E}_{2} \mathrm{y}$ & $\mathrm{E}_{2} \mathrm{~S}$ & $\mathrm{E}_{2} \mathrm{sh}$ & $\mathrm{E}_{2} \mathrm{y}$ & $\mathrm{E}_{2} \mathrm{~S}$ & $\mathrm{E}_{2} \mathrm{sh}$ & $\mathrm{E}_{2} \mathrm{y}$ \\
\hline $\mathrm{E}_{\text {oil }}(\mathrm{mg} / \mathrm{g}$ TOC) & 20.94 & 5.08 & - & 28.31 & 21.79 & - & 10.04 & - & - & 25 & 16.55 & - \\
\hline $\mathrm{E}_{\text {time }}(\mathrm{Ma})$ & 20.5 & 10.5 & - & 27 & 20.5 & - & 14.5 & - & - & 24.5 & 18 & - \\
\hline
\end{tabular}

Table 6. Present day gas expelled for all well.

\begin{tabular}{|c|c|c|c|c|c|c|c|c|c|c|c|c|}
\hline \multirow{2}{*}{$\begin{array}{l}\text { Well No. } \\
\text { Horizons }\end{array}$} & \multicolumn{3}{|c|}{ Chang 7} & \multicolumn{3}{|c|}{ Chang 8} & \multicolumn{3}{|c|}{ WC1 } & \multicolumn{3}{|c|}{ Chang 25} \\
\hline & $\mathrm{E}_{2} \mathrm{~S}$ & $\mathrm{E}_{2} \mathrm{sh}$ & $\mathrm{E}_{2} \mathrm{y}$ & $\mathrm{E}_{2} \mathrm{~S}$ & $\mathrm{E}_{2} \mathrm{sh}$ & $\mathrm{E}_{2} \mathrm{y}$ & $\mathrm{E}_{2} \mathrm{~S}$ & $\mathrm{E}_{2} \mathrm{sh}$ & $\mathrm{E}_{2} \mathrm{y}$ & $\mathrm{E}_{2} \mathrm{~S}$ & $\mathrm{E}_{2} \mathrm{sh}$ & $\mathrm{E}_{2} \mathrm{y}$ \\
\hline $\mathrm{E}_{\text {gas }}(\mathrm{mg} / \mathrm{g} \mathrm{TOC})$ & 46.17 & 10.67 & - & 64.26 & 48.05 & - & 22.02 & - & - & 72.16 & 36.15 & - \\
\hline $\mathrm{E}_{\text {time }}(\mathrm{Ma})$ & 20.5 & 10.5 & - & 27 & 20.5 & - & 14.5 & - & - & 24.5 & 18 & - \\
\hline
\end{tabular}




\section{Acknowledgements}

The Authors are grateful to the Department of Oil and Gas exploration, Faculty of Earth Resources, China University of Geosciences (Wuhan) for their support in terms of data and finance.

\section{References}

[1] Cao, Q., Ye, J., Shen, C. and Tang, D. (2010) Tectonic Uplift History of the Yitong Basin since the Oligocene, Northeast China: Evidence from Apatitefission Track Ages and Geological Relationship. China Academic Journal Electronic Publishing House, 29, 293-300. www.gyig.ac.cn www.springerlink.com

[2] Xu, C., Zhou, Z., Van, D.H.P., Donelick, R.A., Grave, J.D., Ma, C. and Reiners, P.W. (2004) Apatite Fission Track (AFT) Chronology Study in Dabieorogenic Belt. Science in China (Series D: Earth Sciences), 34, 622-634. (In Chinese with English Abstract)

[3] Wang, Y. (2001) The Petroleum System and Accumulation in Yitong Garben. Geologic Publishing House and Petroleum Industry Press, Beijing, 143-173. (In Chinese with English Abstract)

[4] Sun, W., Liu, B. and Li, B. (2004) Fault System and Tectonic Style of the Yitong Graben. Geoscience, 505-601. (In Chinese with English Abstract)

[5] Cheng, J. and Wan, T. (1996) On the Activity of the Tancheng-Lujiang Fault Zone during Cenozoic. Geological Scienceand Technology Information, 15, 35-42.

[6] Sharp, W.D. and Clague, D.A. (2006) 50-Ma Initiation of Hawaiian-Emperor Bend Records Major Change in Pacific Plate Motion. Science, 3131, 10-13. http://dx.doi.org/10.1126/science.1128489

[7] Zhu, G., Liu, G., Niu, M., Song, C. and Wang, D. (2002) Post-Eogene Compressive Activities on the Tan-Lu Fault Zone and Their Deep Processes. Seismology and Geology, 24, 265-277. (In Chinese with English Abstract)

[8] Pickard, G.L. (1964) Descriptive Physical Oceanography: An Introduction. Macmillan, New York.

[9] Haq, B.U. and Al-Qahtani, A.M. (2005) Phanerozoic Cycles of Sea-Level Change on the Arabian Platform. GeoArabia, 2, 127-160.

[10] Haq, B.U. and Shutter, S.R. (2008) A Chronology of Paleozoic Sea-Level Changes. Science, 322, 64-68. http://dx.doi.org/10.1126/science.1161648

\section{Submit or recommend next manuscript to SCIRP and we will provide best service for you:}

Accepting pre-submission inquiries through Email, Facebook, LinkedIn, Twitter, etc. A wide selection of journals (inclusive of 9 subjects, more than 200 journals)

Providing 24-hour high-quality service

User-friendly online submission system

Fair and swift peer-review system

Efficient typesetting and proofreading procedure

Display of the result of downloads and visits, as well as the number of cited articles

Maximum dissemination of your research work

Submit your manuscript at: http://papersubmission.scirp.org/ 